\title{
Phenoxaphosphine-Based Diphosphine Ligands. Synthesis and Application in the Hydroformylation Reaction
}

\author{
Erik Zuidema, ${ }^{\dagger}$ P. Elsbeth Goudriaan, ${ }^{\dagger}$ Bert H. G. Swennenhuis, ${ }^{\dagger}$ Paul C. J. Kamer,,$*$ \\ Piet W. N. M. van Leeuwen, ${ }^{* \dagger, \S}$ Martin Lutz, ${ }^{\perp}$ and Anthony L. Spek ${ }^{\perp}$ \\ ${ }^{\dagger} V$ an 't Hoff Institute for Molecular Sciences, Universiteit van Amsterdam, Nieuwe Achtergracht 166, \\ 1018 WV Amsterdam, The Netherlands, ${ }^{*}$ EaStCHEM, Department of Chemistry, St. Andrews University, \\ St. Andrews, Scotland, U.K., ${ }^{\S}$ Institute of Chemical Research of Catalonia (ICIQ), Avenida Països Catalans, \\ 16, 43007 Tarragona, Spain, and ${ }^{\perp}$ Bijvoet Centre for Biomolecular Research, Utrecht University, \\ Padualaan 8, $3584 \mathrm{CH}$ Utrecht, The Netherlands
}

Received December 3, 2009

\begin{abstract}
The synthesis of a new series of diphosphine ligands based on 2,7-di-tert-butyl-9,9-dimethylxanthene (1), p-tolyl ether (2), ferrocene (3), and benzene (4) backbones, containing one or two 2,8-dimethylphenoxaphosphine moieties, is reported. The ligands were employed in the rhodium-catalyzed hydroformylation of 1 -octene. For all four ligand backbones, introduction of phenoxaphosphine moieties led to an increase in catalytic activity and a decrease in regioselectivity toward the linear aldehyde product. Xanthene-based ligands $1 \mathbf{a}-\mathbf{1} \mathbf{c}$ yielded highly active and regioselective hydroformylation catalysts; ligands containing $p$-tolyl ether and ferrocene backbones $\mathbf{2 a}-\mathbf{2} \mathbf{c}$ and $\mathbf{3 a}-\mathbf{3 c}$ provided less active and less regioselective catalysts. Catalysts containing benzene-derived ligands $\mathbf{4 a}$ and $\mathbf{4 b}$ showed a remarkable preference for the formation of the branched aldehyde product. The coordination behavior of ligands 1-4 under hydroformylation conditions was investigated using high-pressure NMR and IR spectroscopy, revealing the distinct steric and electronic properties of the diphenylphosphine and 2,8-dimethylphenoxaphosphine moieties in ligands 1-4. The phosphacyclic moieties proved to be less basic and less sterically demanding toward other ligands in metal complexes than the acyclic diphenylphosphine moieties. For ligands that contain rigid backbones, the lack of conformational freedom in these phosphacyclic moieties does lead to repulsive interactions between the substituents of the two phosphorus donor atoms, resulting in an increase in the bite angle of the ligand. The low catalytic activity of rhodium catalysts modified by benzene-based ligands $\mathbf{4 a}-\mathbf{4 c}$ was attributed to the quantitative formation of $\mathrm{HRh}(\mathrm{L})_{2}$ under hydroformylation conditions.
\end{abstract}

\section{Introduction}

Due to its large-scale industrial application, the hydroformylation reaction is one of the most studied homogenously catalyzed reactions. The activity and chemo-, regio-, and enantioselectivity of the catalyst system can be influenced to a large extent by ligands coordinated to the catalytically active rhodium, cobalt, or platinum metal centers. In selected cases, clear relationships between ligand structure and catalyst activity and selectivity have been observed. For instance for monodentate phosphorus-based ligands, both Moser et al. and Van Leeuwen et al. have shown that a relationship exists between ligand basicity and catalyst activity and selectivity. ${ }^{1}$ For bidentate ligands the natural bite angle ${ }^{2}$ of the ligand proved to be an important factor. ${ }^{3}$ The increased activity and (in some cases) selectivity observed for ligands

\footnotetext{
*Corresponding authors. E-mail: pcjk@st-andrews.ac.uk; PvanLeeuwen@ICIQ.es.

(1) (a) Van Leeuwen, P. W. N. M.; Roobeek, C. F. J. Organomet. Chem. 1983, 258, 343. (b) Moser, W. R.; Papile, C. J.; Brannon, D. A.; Duwell, R. A.; Weininger, S. J. J. Mol. Catal. 1987, 41, 271.

(2) Casey, C. P.; Whiteker, G. T. Isr. J. Chem. 1990, 30, 299.

(3) Casey, C. P.; Whiteker, G. T.; Melville, M. G.; Petrovich, L. M.; J. A. Gavney, J.; Powell, D. R. J. Am. Chem. Soc. 1992, 114, 5535.
}

with a bite angle of approximately $120^{\circ}$ were attributed to the preferred bisequatorial coordination mode of these ligands in the trigonal-bipyramidal rhodium complexes involved in the hydroformylation reaction (Figure 1). On the basis of this observation, several wide bite angle diphosphine ligands were successfully developed. ${ }^{4}$ The coordination mode of the diphosphine ligand is however not the sole factor governing the regioselectivity of the catalyst. ${ }^{5}$ Just as for monodentate

(4) (a) Van Der Veen, L. A.; Keeven, P. H.; Schoemaker, G. C.; Reek, J. N. H.; Kamer, P. C. J.; Van Leeuwen, P. W. N. M.; Lutz, M.; Spek, A. L. Organometallics 2000, 19, 872. (b) Bohnen, H.; Herwig, J.; Joerg, A.; Hoff, D.; Surm, S.; Van Leeuwen, P. W. N. M.; Bronger, R. P. J.; Stelzer, O. DE 10225282, 2003. (c) Bohnen, H.; Herwig, J. WO 2002068371, 2002. (d) Bohnen, H.; Herwig, J. WO 2002068369, 2002. (e) Ahlers, W.; Paciello, R.; Vogt, D.; Hofmann, P. WO 2002083695, 2002. (f) Ahlers, W.; Wiebelhaus, D.; Paciello, R.; Bartsch, M.; Baumann, R.; Vogt, D.; Hewat, A. WO 2002022261, 2002. (g) Rainer, P.; Ahlers, W.; Mackewitz, T.; Paciello, R.; Volland, M. WO 2005039762, 2005. (h) Van Leeuwen, P. W. N. M.; WalczukGusciora, E. B.; Grimmer, N. E.; Kamer, P. C. J. WO 2005049537, 2005. (i) Ahlers, W.; Roeper, M.; Hofmann, P.; Warth, D. C. M.; Paciello, R. WO $2001058589,2001$.

(5) (a) Van Der Veen, L. A.; Boele, M. D. K.; Bergman, F. R.; Kamer, P. C. J.; Van Leeuwen, P. W. N. M.; Goubitz, K.; Fraanje, J.; Schenk, H.; Bo, C. J. Am. Chem. Soc. 1998, 120, 11616. (b) Nettekoven, U.; Kamer, P. C. J.; Widhalm, M.; Van Leeuwen, P. W. N. M. Organometallics 2000, 19, 4596. (c) Freixa, Z.; Van Leeuwen, P. W. N. M. J. Chem. Soc., Dalton Trans. 2003, 10, 1890 . 


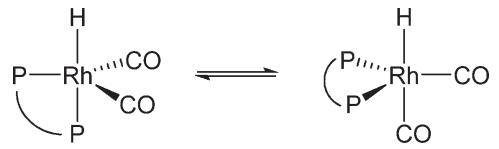

Figure 1. Equatorial-axial (left) and bisequatorial (right) coordination modes of bidentate ligands in the resting state of the hydroformylation catalyst.

ligands, the electronic properties of the donor moieties ${ }^{6}$ and the steric bulk of the ligand ${ }^{5 \mathrm{c}, 7}$ have a profound influence on the activity and selectivity of the catalyst system.

Several authors have also reported that enclosing the ligand's phosphorus donor atom(s) inside a cyclic structure leads to more stable, active, and/or regio- and enantioselective catalysts. ${ }^{8}$ The increased regio- and enantioselectivity of catalysts containing phosphacyclic ligands compared to catalysts containing noncyclic ligands are often attributed to a more effective steric interaction between ligand and substrate, caused by the rigid structure of the phosphacyclic ligand. Indeed, in the rhodium-catalyzed asymmetric hydroformylation of prochiral olefins, where effective transfer of chirality from the ligand to the substrate is crucial, the highest enantioselectivities are obtained for catalysts containing phosphacyclic ligand structures. ${ }^{9}$ The increase in activity observed for many phosphacyclic ligands has been ascribed to a lower basicity of the phosphorus moiety in the cyclic ligand structure. ${ }^{8 \mathrm{a}, \mathrm{b}, \mathrm{d}, 10}$ Early studies have suggested that the lower basicity of cyclic phosphite or phosphoramidite structures compared to their noncyclic analogues is caused by a less effective overlap between the phosphorus and oxygen or nitrogen lone-pair orbitals. ${ }^{11}$ Alder and co-workers have shown that the valence angles around the phosphorus atom of noncyclic phosphine compounds increase upon protonation. ${ }^{12}$ Consequently, cyclic structures that impose large valence angles yielded highly basic phosphorus compounds. Orpen et al. showed by detailed analysis of known crystal structures of a large number of metal

(6) (a) Unruh, J. D.; Christenson, J. R. J. Mol. Catal. 1982, 14, 19. (b) Casey, C. P.; Paulsen, E. L.; Beuttenmueller, E. W.; Proft, B. R.; Petrovich, L. M.; Matter, B. A.; Powel, D. R. J. Am. Chem. Soc. 1997, 119, 11817. (c) Casey, C. P.; Paulsen, E. L.; Beuttenmueller, E. W.; Proft, B. R.; Matter, B. A.; Powel, D. R. J. Am. Chem. Soc. 1999, 121, 63.

(7) (a) Carbo, J. J.; Maseras, F.; Bo, C.; Van Leeuwen, P. W. N. M. J. Am. Chem. Soc. 2001, 123, 7630. (b) Landis, C. R.; Uddin, J. J. Chem. Soc., Dalton Trans. 2002, 729.

(8) (a) Van Der Veen, L. A.; Kamer, P. C. J.; Van Leeuwen, P. W. N. M. Organometallics 1999, 18, 4765. (b) Van Der Veen, L. A.; Kamer, P. C. J.; Van Leeuwen, P. W. N. M. Angew. Chem., Int. Ed. 1999, 38, 336. (c) Bronger, R. P. J.; Bermon, J. P.; Herwig, J.; Kamer, P. C. J.; Van Leeuwen, P. W. N. M. Adv. Synth. Catal. 2004, 346, 789. (d) Haddow, M. F.; Middleton, A. J.; Orpen, A. G.; Pringle, P. G.; Papp, R. J. Chem. Soc., Dalton Trans. 2009, 202.

(9) (a) Nozaki, K.; Sakai, N.; Nanno, T.; Higashijima, T.; Mano, S.; Horiuchi, T.; Takaya, H. J. Am. Chem. Soc. 1997, 119, 4413. (b) Breeden, S.; Cole-Hamilton, D. J.; Foster, D. F.; Schwarz, G. J.; Wills, M. Angew. Chem., Int. Ed. 2000, 39, 4106. (c) Dieguez, M.; Pamies, O.; Claver, C. Tetrahedron: Assymmetry 2004, 15, 2113. (d) Clark, T. P.; Landis, C. R.; Freed, S. L.; Klosin, J.; Abboud, K. A. J. Am. Chem. Soc. 2005, 127, 5040. (e) Axtell, A. T.; Cobley, C. J.; Klosin, J.; Whiteker, G. T.; Zanotti-Gerosa, A.; Abboud, K. A. Angew. Chem., Int. Ed. 2005, 44, 5834. (f) Axtell, A. T.; Klosin, J.; Abboud, K. A. Organometallics 2006, 25, 5003.

(10) (a) Tanaka, M.; Ikeda, Y.; Ogata, I. Chem. Lett. 1975, 1115. (b) Hayashi, T.; Tanaka, M.; Ogata, I. J. Mol. Catal. 1979, 6, 1. (c) Hayashi, T.; Tanaka, M.; Ikeda, Y.; Ogata, I. Bull. Chem. Soc. Jpn. 1979, 52, 2605. (d) Hobbes, C. F.; Knowles, W. S. J. Org. Chem. 1981, 46, 4422.

(11) (a) Verkade, J. G. Coord. Chem. Rev. 1972, 9, 1. (b) Verkade, J. G. Bioinorg. Chem. 1974, 3, 165. (c) Albright, J. O.; Tanzella, F. L.; Verkade, J. G. J. Coord. Chem. 1976, 6, 225.

(12) Alder, R. W.; Butts, C. P.; Orpen, A. G.; Read, D.; Oliva, J. M. J. Chem. Soc., Perkin Trans. 2 2001, 282. complexes that the angles around the phosphorus atom decrease with increasing $\pi$-back-donation from the metal to the ligand. ${ }^{13}$ Most cyclic ligand structures applied in the hydroformylation reaction impose small valence angles around the phosphorus atom and are therefore expected to be less effective $\sigma$-donors than their acyclic analogues, while favoring back-donation from the metal to the ligand. This relationship between $\mathrm{C}-\mathrm{P}-\mathrm{C}$ angles, ligand electronic properties, and catalyst activity in the hydroformylation was recently elegantly confirmed by Pringle and co-workers using a range of isosteric and isoelectronic diphosphine ligands containing phosphacyclic moieties of different ring size. ${ }^{8 \mathrm{~d}}$

In addition to this angle effect, it has been postulated that, for phosphine-based phosphacyclic ligands containing unsaturated moieties, conjugation between the phosphorus orbitals and the $\pi$-system of the ligand is responsible for the unusually high activity in the hydroformylation reaction observed for these ligands. ${ }^{8 a, 10 b, c, 14}$ The degree of conjugation in this type of phosphine compound, however, remains heavily debated. ${ }^{15}$ Computational studies on phosphole-type compounds have shown that the interaction between the phosphorus orbitals and the $\pi$-orbitals on the cyclic compound is minimal due to the pyramidal structure around the phosphorus atom. ${ }^{16}$ It should be noted that systematic computational studies on the coordination behavior of these compounds in transition metal complexes are lacking.

We previously reported the synthesis and application of wide bite angle ligands that contain dibenzophosphole and phenoxaphosphine phosphacyclic moieties. ${ }^{4 a, 8 c, 14}$ The resulting catalysts proved an order of magnitude more active in the hydroformylation of terminal alkenes than their acyclic analogues ${ }^{4 \mathrm{a}}$ and could even be applied in the hydroformylation of internal alkenes to linear aldehydes. ${ }^{8 \mathrm{c}}$ In order to further explore the unusual activity and selectivity of hydroformylation catalysts modified by these phosphacyclic ligand structures, we have synthesized several bidentate ligands containing cyclic 2,8-dimethylphenoxaphosphine moieties, based on the xanthene, $p$-tolyl ether, ferrocene, and benzene ligand backbones (Chart 1). The "parent" diphenylphosphine-substituted ligands have been shown to span a wide range of ligand bite angles, ${ }^{17}$ and all four have previously been applied in the hydroformylation reaction. ${ }^{5 \mathrm{~b}, 6 \mathrm{a}, 8 \mathrm{a}, 18}$ New phosphacyclic ligand structures were generated by replacing one or both diphenylphosphine groups by 2,8-dimethylphenoxaphosphine moieties. The catalytic performance of the new ligands in the hydroformylation of 1-octene was evaluated. In addition, the coordination behavior of the bidentate ligands under hydroformylation conditions was studied using both high-pressure NMR and IR spectroscopic techniques.

(13) (a) Orpen, A. G.; Connelly, N. G. Chem. Commun. 1985, 1310. (b) Orpen, A. G.; Connelly, N. G. Organometallics 1990, 9, 1206.

(14) Bronger, R. P. J.; Kamer, P. C. J.; Van Leeuwen, P. W. N. M. Organometallics 2003, 22, 5358 .

(15) Nyulaszi, L. Chem. Rev. 2001, 101, 1229.

(16) Schleyer, P. v. R.; Freeman, P. K.; Jiao, H.; Goldfuss, B. Angew. Chem., Int. Ed. Engl. 1995, 34, 337.

(17) Dierkes, P.; Van Leeuwen, P. W. N. M. J. Chem. Soc., Dalton Trans. 1999, 1519

(18) (a) Kranenburg, M.; Van Der Burgt, Y. E. M.; Kamer, P. C. J.; Van Leeuwen, P. W. N. M. Organometallics 1995, 14, 3081. (b) Bianchini, C.; Oberhauser, W.; Orlandini, A.; Gianelli, C.; Frediani, P. Organometallics 2005, 24, 3692 . 
Chart 1. Ligands Used in This Study<smiles>CC(C)(C)c1cc2c(c(-c3ccccc3)c1)C(C)(C)c1cc(C(C)(C)C)cc(-c3ccccc3)c1O2</smiles><smiles>Cc1ccc(Oc2ccc(C)cc2-c2ccccc2)c(P)c1</smiles><smiles></smiles>

3a<smiles>Pc1cccc(Pc2ccccc2)c1P</smiles>

$4 a$<smiles>Cc1ccc(Oc2ccc(C)cc2P(c2ccccc2)c2cc(C)ccc2Oc2ccccc2)c(-c2ccccc2)c1</smiles><smiles>Cc1ccc2c(c1)P(c1ccccc1)c1cc(C)ccc1O2</smiles><smiles>Cc1ccc2c(c1)P(c1ccccc1P(C)(C)(F)(F)(F)c1ccccc1)c1cc(C)ccc1O2</smiles>

4b<smiles>Cc1ccc2c(c1)P(c1ccccc1)c1ccc(C)cc1P(c1ccccc1)c1cc(C)ccc1O2</smiles><smiles>Cc1cccc(P2c3cccc(c3)Oc3ccc(Cc4ccc5c(c4)P(c4ccccc4)c4cc(C)ccc4O5)cc32)c1</smiles>

4c

Scheme 1. Synthesis of Benzene-Based Ligands ${ }^{a}$<smiles>Cc1ccc2c(c1)P(c1ccccc1P)c1cc(C)ccc1O2</smiles>
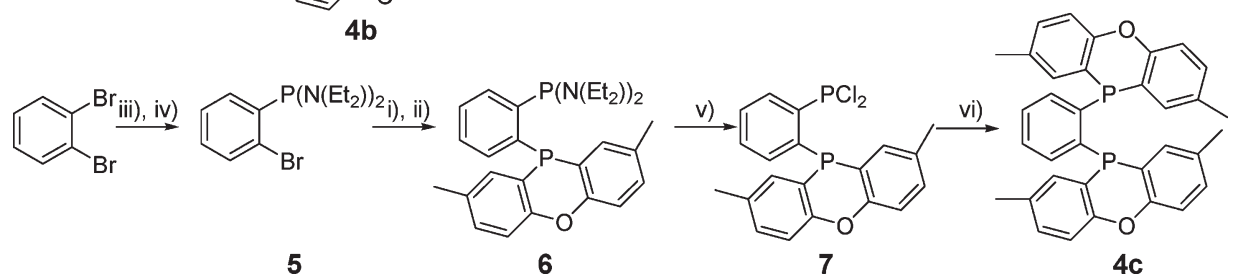

${ }^{a}$ (i) $n$-Butyllithium, diethyl ether, $-80{ }^{\circ} \mathrm{C}$; (ii) 2,8 -dimethylphenoxaphosphine chloride, THF, $-80{ }^{\circ} \mathrm{C}$; (iii) $n$-butyllithium, ether/pentane/THF, $-120^{\circ} \mathrm{C}$; (iv) bis(diethylamino)phosphine chloride, ether/pentane $/ \mathrm{THF},-120^{\circ} \mathrm{C}$; (v) $\mathrm{PCl}_{3}, 50^{\circ} \mathrm{C}$; (vi) $2,2^{\prime}$-dilithio- $p$-tolyl ether, diethyl ether, $-80^{\circ} \mathrm{C}$.

\section{Results}

2.1. Ligand Synthesis. The synthesis of ligands $\mathbf{1 a}-\mathbf{1 c}$ was previously reported by Van der Veen et al. ${ }^{4 a}$ Symmetrical p-tolyl ether- and ferrocene-based ligands $\mathbf{2 c}$ and $\mathbf{3 c}$ were synthesized via direct dilithiation of the backbone or by bromide-lithium exchange of the dibrominated backbone, followed by a reaction with two equivalents of 2,8-dimethylphenoxaphosphinous chloride. For the ligands containing two different phosphorus moieties based on these backbones, $\mathbf{2 b}$ and $\mathbf{3 b}$, the two phosphine donor groups were introduced sequentially, starting from dibromo-substituted ligand backbones. The synthesis of 1-bromo-1'-diphenylphosphinoferrocene was previously reported by Butler and co-workers. ${ }^{19}$ Also for $2,2^{\prime}$-dibromo- $p$-tolyl ether, bromide-lithium exchange of a single bromide moiety occurred selectively. In contrast to the synthesis of ferrocene ligand $\mathbf{3 b}$, initial introduction of the phenoxaphosphine moiety, generating 2-bromo$2^{\prime}$-(2,8-dimethylphenoxaphosphino)-p-tolyl ether (8), proved crucial for obtaining ligand $\mathbf{2} \mathbf{b}$ selectively. Initial introduction of the diphenylphosphine group in the synthesis of $\mathbf{2} \mathbf{b}$ led to cleavage of one of the phosphorus-phenyl bonds and the

(19) Butler, I. R.; Davies, R. L. Synthesis 1996, 11, 1350. formation of a phenoxaphosphine structure during the second bromide-lithium exchange reaction. Introducing the phenoxaphosphine moiety first prevented the occurrence of this side reaction.

Dissymmetric benzene-based ligand $\mathbf{4 b}$ was synthesized directly from previously reported $o$-(bromophenyl)diphenylphosphine. ${ }^{20}$ Symmetric ligand $4 \mathbf{c}$ was synthesized in a sequence of steps (Scheme 1), starting from 1,2-dibromobenzene. Direct reaction of 1-lithio-2-bromobenzene and 2,8-dimethylphenoxaphosphinous chloride at low temperature resulted in the formation of significant amounts of unidentified side products. Reetz and co-workers have reported the synthesis of 1,2-bis(dichlorophosphino)benzene, starting from 1,2-dibromobenzene, butyllithium, and bis(diethylamino)phosphinous chloride. ${ }^{21}$ Using a similar approach, we synthesized 2-bromophenyl-bis(diethylamino)phosphine 5. Reaction of $\mathbf{5}$ with butyllithium and 2,8-dimethylphenoxaphosphine chloride yielded diphosphine 6. The bis(diethylamino)phosphine moiety was subsequently converted to a phosphonous dichloride moiety using $\mathrm{PCl}_{3}$. In the final

(20) Machnitzki, P.; Nickel, T.; Stelzer, O.; Landgrafe, C. Eur. J. Inorg. Chem. 1998, 1029.

(21) Reetz, M. T.; Moulin, D.; Gosberg, A. Org. Lett. 2001, 3, 4083. 

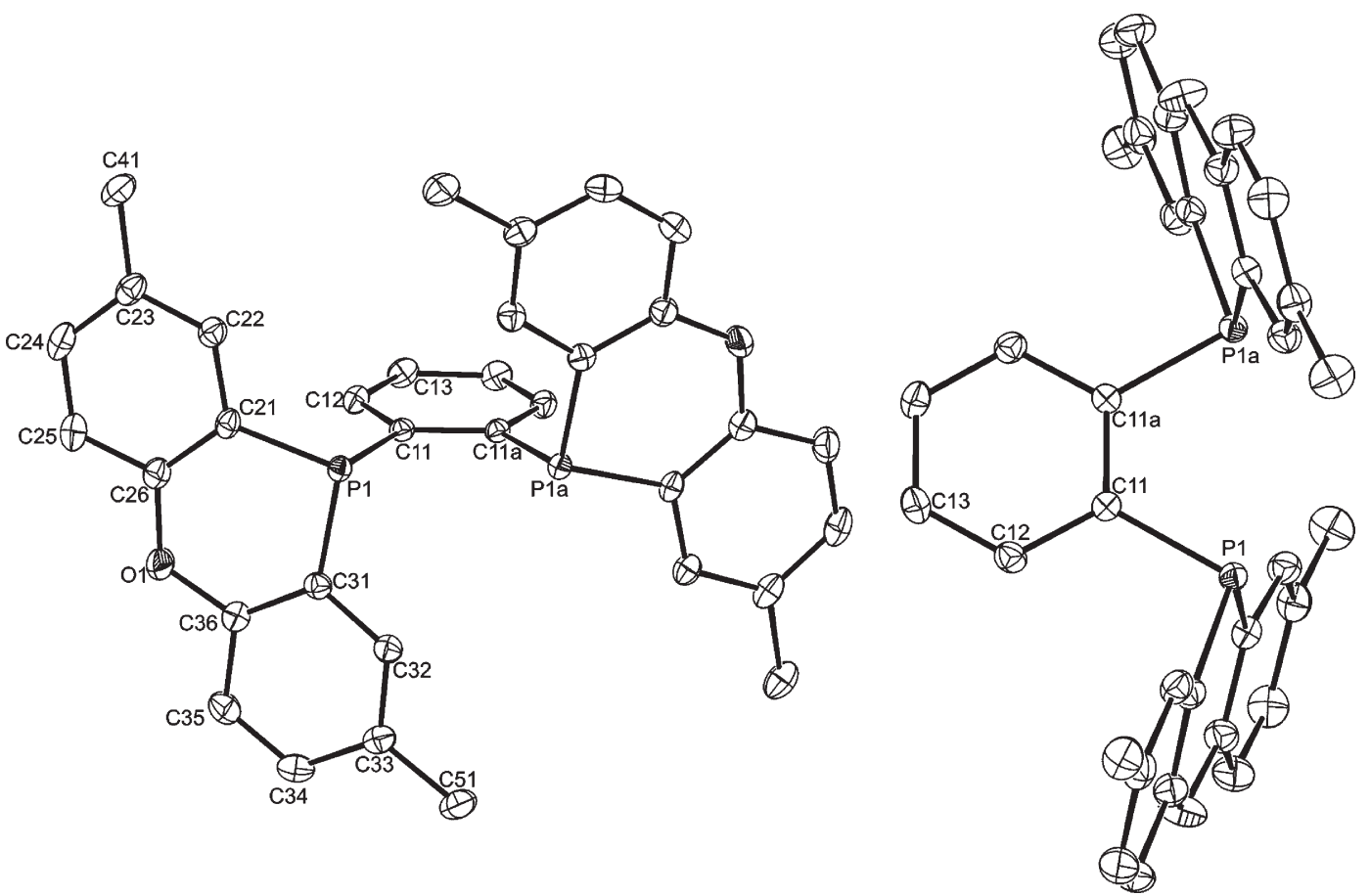

Figure 2. Two separate views of the crystal structure of ligand 4c. Displacement ellipsoids are drawn at the 50\% probability level. Symmetry operation a: $1-x, y, 0.5-z$.

Table 1. Selected Distances and Angles in the Crystal Structure of Ligand 4c

\begin{tabular}{|c|c|c|c|c|c|}
\hline \multicolumn{2}{|c|}{ distances $(\AA)$} & \multicolumn{2}{|c|}{ angles (deg) } & \multicolumn{2}{|c|}{ interplanar angles (deg) } \\
\hline $\mathrm{P} 1-\mathrm{C} 11$ & $1.8604(11)$ & $\mathrm{C} 11-\mathrm{P} 1-\mathrm{C} 21$ & $100.83(5)$ & $\mathrm{Ph} 2-\mathrm{Ph} 3$ & $2.40(6)$ \\
\hline $\mathrm{P} 1-\mathrm{C} 21$ & $1.8140(12)$ & $\mathrm{C} 11-\mathrm{P} 1-\mathrm{C} 31$ & $100.55(5)$ & & \\
\hline $\mathrm{P} 1-\mathrm{C} 31$ & $1.8206(12)$ & $\mathrm{C} 21-\mathrm{P} 1-\mathrm{C} 31$ & $98.38(5)$ & & \\
\hline $\mathrm{P} 1-\mathrm{P} 1 \mathrm{a}$ & $3.2553(6)$ & $\mathrm{C} 26-\mathrm{O} 1-\mathrm{C} 36$ & $122.60(10)$ & & \\
\hline $\mathrm{P} 1-\mathrm{O} 1$ & $3.2328(13)$ & & & & \\
\hline
\end{tabular}

step, this species was reacted with $2,2^{\prime}$-dilithio- $p$-tolyl ether, forming ligand $\mathbf{4 c}$. For this ligand, crystals suitable for X-ray diffraction were obtained. The elucidated structure is shown in Figure 2.

$\mathbf{4 c}$ crystallizes in the centrosymmetric space group $C 2 / c$, and the molecule has an exact, crystallographic 2-fold symmetry. The phosphorus-phosphorus distance observed in the crystal structure of $\mathbf{4 c}$ corresponds to a natural bite angle of $89.4^{\circ}$ (at a $\mathrm{M}-\mathrm{P}$ distance of $2.315 \AA$ ), considerably larger than the value of $83^{\circ}$ reported for 1,2-bis(diphenylphosphino)benzene (4a). ${ }^{17}$ Van Leeuwen et al. have previously observed a similar increase in bite angle going from ligand 1a to ligand 1c and attributed this to steric repulsion between the two phosphacyclic moieties in ligand 1c. ${ }^{14}$ The geometry of $\mathbf{4 c}$ in the crystal structure minimizes both the steric repulsion between the two rigid phosphacyclic structures and the electronic repulsion between the lone pairs of the two phosphorus atoms. The two phosphacyclic moieties are almost planar, and the geometry around the phosphorus atoms is trigonal pyramidal. The $\mathrm{C}-\mathrm{P}-\mathrm{C}$ angle in the phosphacyclic ring is somewhat smaller than the other two $\mathrm{C}-\mathrm{P}-\mathrm{C}$ angles in the structure.

The natural bite angles $\left(\beta_{\mathrm{n}}\right)$ of ligands $\mathbf{1 - 4}$ were determined using molecular mechanics-based calculations on rhodium(diphosphine) complexes following the methodology developed by Casey and Whiteker. ${ }^{2}$ The optimized rhodium(diphosphine) structures were subsequently used to evaluate the steric properties of the ligands using the solid
Table 2. Calculated Natural Bite Angles, Flexibility Ranges, and Solid Angles for Ligands 1-4

\begin{tabular}{|c|c|c|c|}
\hline ligand & $\beta_{\mathrm{n}}(\operatorname{deg})^{a}$ & flexibility range (deg) $)^{a, b}$ & solid angle $(\%)^{c}$ \\
\hline 1a & 113.5 & $100-131$ & 50.6 \\
\hline $1 \mathrm{~b}$ & 119.2 & $104-137$ & 49.1 \\
\hline $1 c$ & 120.6 & $104-136$ & 45.8 \\
\hline $2 a$ & 108.0 & $93-124$ & 46.3 \\
\hline $2 b$ & 106.6 & $94-123$ & 45.1 \\
\hline $2 c$ & 106.8 & $94-124$ & 43.3 \\
\hline $3 \mathbf{a}$ & 113.4 & $94-131$ & 46.4 \\
\hline $3 b$ & 109.7 & $94-125$ & 46.6 \\
\hline $3 c$ & 109.8 & $95-123$ & 47.4 \\
\hline $4 a$ & 86.0 & $78-93$ & 37.5 \\
\hline $4 b$ & 85.6 & $78-93$ & 38.3 \\
\hline $4 c$ & 84.7 & $78-92$ & 38.1 \\
\hline
\end{tabular}

${ }^{a}$ Calculated using the method of Casey and Whiteker. ${ }^{2 b}$ Accessible bite angle range within $3 \mathrm{kcal} \mathrm{mol}^{-1}$ excess strain energy of $\beta_{\mathrm{n}}$. ${ }^{c}$ Calculated using the method of White and co-workers, ${ }^{22}$ as implemented in the Steric program. ${ }^{23}$

angle methodology introduced by White et al. ${ }^{22}$ The calculated bite angles and solid angles are reported in Table 2.

As expected, the different ligand backbones span a wide range of natural bite angles. The calculated bite angles and flexibility ranges are in line with previous observations that xanthene-based ligands $\mathbf{1}$ preferentially adopt

(22) (a) White, D.; Tavener, B. C.; Leach, P. G. L.; Coville, N. J. J. Organomet. Chem. 1994, 478, 205. (b) White, D.; Tavener, B. C.; Coville, N. J.; Wade, P. W. J. Organomet. Chem. 1995, 495, 41.

(23) Taverner, B. C. Steric 1.2.8, www.gh.wits.ac.za/craig/steric. 
Table 3. Results of the Hydroformylation of 1-Octene Using Ligands $1-4^{a}$

\begin{tabular}{|c|c|c|c|c|}
\hline ligand & $\mathrm{TOF}^{b}$ & $1 / \mathrm{b}$ & $\%$ isomers $^{c}$ & $\% n$-aldehyde \\
\hline & 403 & 2.8 & 77 & 17 \\
\hline $1 a$ & 163 & 44 & 5.0 & 93 \\
\hline $1 b$ & 346 & 31 & 5.5 & 93 \\
\hline $1 c$ & 812 & 22 & 9.8 & 86 \\
\hline $2 a$ & 38 & 7.2 & 2.3 & 86 \\
\hline $2 b$ & 77 & 3.2 & 2.5 & 74 \\
\hline $2 c$ & 34 & 3.0 & 2.6 & 74 \\
\hline $3 a$ & 79 & 5.3 & 4.8 & 80 \\
\hline $3 b$ & 80 & 1.9 & 1.6 & 65 \\
\hline $3 c$ & 224 & 1.5 & 5.0 & 56 \\
\hline $4 a$ & 32 & 0.9 & 3.1 & 46 \\
\hline $4 b$ & 89 & 0.6 & 7.0 & 35 \\
\hline \multicolumn{5}{|l|}{$4 c$} \\
\hline $\begin{array}{l}\quad{ }^{a} T \\
\text { strate } \\
\mathrm{h}^{-1} \cdot{ }^{c} \mathrm{I} \\
{ }^{d} \text { Perce }\end{array}$ & $\begin{array}{l}{ }^{\circ} \mathrm{C}, p \mathrm{C} \\
0: 637 . \\
\text { tage oc } \\
\text { nonan. }\end{array}$ & $\begin{array}{l}p \mathrm{H}_{2} \\
\text { over } \\
\text { omer } \\
1 \text { pro }\end{array}$ & $\begin{array}{l}\text { bar, }[\mathrm{Rh}]= \\
\text { ency in mol } \\
\text { ll products fo } \\
\text { formed in the }\end{array}$ & $\begin{array}{l}\text { mM, Rh:L:sub- } \\
\text { yde (mol Rh) } \\
\text { in the reaction. } \\
\text { tion. }\end{array}$ \\
\hline
\end{tabular}

a bisequatorial coordination mode in trigonal-bipyramidal complexes. ${ }^{4 a, 8 a}, 14$ For benzene-based ligands $\mathbf{4}$, this coordination mode is predicted to be inaccessible, and consequently these ligands will prefer an equatorial-axial coordination mode. Flexible ligands $\mathbf{2}$ and $\mathbf{3}$ are predicted to be capable of accommodating both coordination modes in trigonalbipyramidal complexes. The calculated solid angles follow the observed bite angle trend; wide bite angle ligands $\mathbf{1}$ are predicted to induce the most steric hindrance around the metal center in transition metal complexes. For ligands having the same backbone, the differences in bite angle are much smaller. It was already reported that on going from ligand 1a to 1c, the natural bite angle of the ligand increases due to steric repulsion between the two rigid phosphacyclic moieties in ligand 1c. ${ }^{14}$ Interestingly, the calculated solid angles in xanthene-based ligands $\mathbf{1}$ and $p$-tolyl ether-based ligands $\mathbf{2}$ decrease when the diphenylphosphine moieties of the ligands are replaced by phenoxaphosphine moieties, suggesting that these phosphacyclic moieties impose less steric hindrance around the metal center than acyclic diphenylphosphine moieties. For ligands $\mathbf{3}$ and $\mathbf{4}$ both the calculated bite angles and solid angles remain nearly constant. Steric differences between the phenoxaphosphine and diphenylphosphine moieties in these ligands are relatively small.

2.2. Hydroformylation of 1-Octene. The catalytic performance of rhodium diphosphine catalysts containing ligands 1-4 in the hydroformylation of 1-octene was investigated. The hydroformylation reactions were performed at $80{ }^{\circ} \mathrm{C}$ under an atmosphere of 20 bar of $\mathrm{CO} / \mathrm{H}_{2}$ (1:1) using a $1.0 \mathrm{mM}$ solution of rhodium catalyst prepared in situ from $\mathrm{Rh}(\mathrm{CO})_{2}$ (acetylacetonate) and 10 equivalents of diphosphine ligand. The production of nonanal, 2-methyloctanal, and octene isomers was determined using gas chromatography. Turnover frequencies and regioselectivities were determined as average values at $15-20 \%$ alkene conversion. The results are shown in Table 3.

The catalytic performance of the unmodified rhodium catalyst in the hydroformylation of terminal alkenes was

(24) Lazzaroni, R.; Pertici, P.; Bertozzi, S.; Fabrizi, G. F. J. Mol. Catal. 1990, 58, 75 .

(25) (a) Feng, J. H.; Garland, M. Organometallics 1999, 18, 417. (b) Liu, G. W.; Volken, R.; Garland, M. Organometallics 1999, 18, 3429.

(26) (a) Horvath, I. Organometallics 1986, 5, 2333. (b) Van Rooy, A.; Kamer, P. C. J.; Van Leeuwen, P. W. N. M.; Goubitz, K.; Fraanje, J.; Veldman, N.; Spek, A. L. Organometallics 1996, 15, 835.

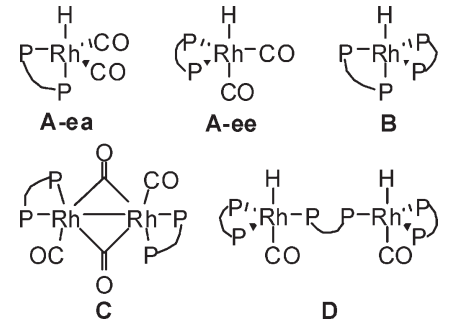

Figure 3. Complexes formed under hydroformylation conditions.

previously investigated extensively by both Lazzaroni et al. ${ }^{24}$ and Garland et al. ${ }^{25}$ Also under our experimental conditions, high hydroformylation rates are observed for this catalyst system, accompanied by high rates of alkene isomerization. At low conversion of 1-octene, the catalyst system shows a surprisingly high $1 / \mathrm{b}$ ratio of 2.8 for the formation of aldehyde products. At higher octene conversions, we observe a decrease in the regioselectivity of the catalyst system due to the hydroformylation of alkene isomerization products.

Xanthene-based ligands $\mathbf{1} \mathbf{a}^{8 \mathrm{a}}$ and $\mathbf{1} \mathbf{c}^{8 \mathrm{c}}$ and ferrocene-based ligand $3 a^{5 b, 6 a, 18 b}$ were previously applied as ligands in the rhodium-catalyzed hydroformylation of 1-alkenes. The xanthene-based ligands yielded highly active and regioselective catalyst systems, while ferrocene-based ligand 3a was shown to be significantly less active and regioselective in the hydroformylation of 1-alkenes. Also in this study, the most active catalyst systems are obtained for xanthene-based ligands 1. Ferrocene-based ligands 3 yielded moderately active catalyst systems, and $p$-tolyl ether-based ligands 2 and benzene-based ligands $\mathbf{4}$ formed the least active hydroformylation catalysts. As a general trend, a decrease in bite angle (and solid angle) of the diphosphine ligand leads to a lower regioselectivity in the hydroformylation of 1-octene. Catalysts modified by benzene-based ligands $\mathbf{4 a}$ and $\mathbf{4 b}$ show a remarkable preference for the formation of the branched aldehyde product in the hydroformylation of 1-octene.

For all four ligand backbones, introduction of phosphacyclic moieties leads to an increase in catalytic activity, accompanied by a decrease in regioselectivity toward the linear aldehyde product and an increased formation of octene isomers. $P$-tolyl ether-based ligand $\mathbf{2 c}$, however, exhibits a significantly lower catalytic activity than both ligand $\mathbf{2 a}$ and $\mathbf{2 b}$. Van der Veen and co-workers previously reported similar observations for the related bis(phenoxaphosphino)-p-tert-butyl-diphenyl-ether ligand ${ }^{4 a}$ and attributed this to the rigid equatorial-axial coordination of the ligand in the resting state of the catalyst A-ea (Figure 3). Surprisingly, benzene-based ligand $\mathbf{4 c}$ proved to be completely inactive in the hydroformylation of 1-octene under the experimental conditions.

2.3. Complex Characterization. For all ligands, the complexes formed under hydroformylation conditions were studied using high-pressure variable-temperature NMR and in situ IR spectroscopy. In order to facilitate the comparison between the hydroformylation results and the spectroscopic data, the in situ IR spectroscopic experiments were performed at actual catalytic rhodium $(1.0 \mathrm{mM})$ and ligand (10.0 mM) concentrations. Due to the relatively low sensitivity of the NMR technique, the NMR spectroscopic studies required significantly higher rhodium $(12 \mathrm{mM})$ and ligand (26 $\mathrm{mM})$ concentrations. Upon reacting $\mathrm{Rh}$ (acetylacetonate)$(\mathrm{CO})_{2}$ with an excess of ligand under an atmosphere of $\mathrm{CO} / \mathrm{H}_{2}$ 
Table 4. High-Pressure NMR Spectroscopic Data ${ }^{a}$

\begin{tabular}{|c|c|c|c|c|c|c|c|}
\hline $\mathrm{L}$ & structure & $\delta^{31} \mathrm{P}(\mathrm{ppm})$ & $J_{\mathrm{Rh}, \mathrm{P}}(\mathrm{Hz})$ & $J_{\mathrm{P}, \mathrm{P}}(\mathrm{Hz})$ & $\delta^{1} \mathrm{H}(\mathrm{ppm})$ & $\left|J_{\mathrm{P}, \mathrm{H}}\right|(\mathrm{Hz})$ & $J_{R \mathrm{~h}, \mathrm{H}}(\mathrm{Hz})$ \\
\hline $1 a$ & A & 19.9(d) & 151 & & $-8.4(\mathrm{dt})$ & 17 & 7 \\
\hline \multirow[t]{2}{*}{$1 b$} & $\mathbf{A}$ & $-24.8(\mathrm{dd})$ & 150 & 73 & $-8.9(\mathrm{bd})$ & & 11 \\
\hline & & 15.9(dd) & 141 & 73 & & & \\
\hline 1c & $\mathbf{A}$ & $-22.9(\mathrm{~d})$ & 151 & & $-9.1(b t)$ & 12 & \\
\hline $2 a$ & $\mathbf{A}$ & $26.6(d)$ & 117 & & $-8.6(\mathrm{dt})$ & 47 & 11 \\
\hline \multirow[t]{2}{*}{$2 b$} & A & $-19.6(\mathrm{dd})$ & 141 & 23 & $-9.2(\mathrm{ddd})$ & $116 ;-19^{b}$ & 11 \\
\hline & & $29.2(\mathrm{dd})$ & 66 & 23 & & & \\
\hline \multirow[t]{2}{*}{$2 c$} & $\mathbf{A}$ & $-20.0(\mathrm{~d})$ & 128 & & $-9.0(\mathrm{dt})$ & 33 & 8 \\
\hline & $\mathrm{C}$ & $-37.4(\mathrm{~m})$ & $159 ; 9$ & 67 & & & \\
\hline 3a & A & $31.7(\mathrm{~d})$ & 124 & & $-8.9(\mathrm{dt})$ & 42 & 9 \\
\hline \multirow[t]{2}{*}{$3 b$} & $\mathbf{A}$ & $-11.5(\mathrm{bd})$ & 133 & & $-9.3(\mathrm{dd})$ & 88 & 8 \\
\hline & & 33.9(bd) & 109 & & & & \\
\hline \multirow[t]{3}{*}{$3 c$} & $\mathbf{A}$ & $-8.1(\mathrm{~d})$ & 130 & & $-9.1(\mathrm{dt})$ & 82 & 9 \\
\hline & D & $-6.6(\mathrm{~m})$ & 159 & 127 & $-9.0(\mathrm{bd})$ & - & 11 \\
\hline & & $-5.7(\mathrm{~m})$ & 165 & 127 & & & \\
\hline \multirow[t]{3}{*}{$4 a$} & A & $62.7(d)$ & 118 & & $-8.4(\mathrm{dt})$ & 61 & 10 \\
\hline & B & $59.2(d)$ & 143 & & $-9.6(\mathrm{bm})$ & & \\
\hline & $\mathrm{C}$ & $43.6(\mathrm{~m})$ & $136 ; 3$ & 54 & & & \\
\hline \multirow[t]{2}{*}{$4 b$} & B & 23.3(ddd) & 143 & $53 ; 46$ & $-9.5(\mathrm{bdt})$ & 40 & \\
\hline & & $59.6(\mathrm{ddd})$ & 146 & $53 ; 46$ & & & \\
\hline $4 c$ & B & $33.5(\mathrm{~d})$ & 152 & & $-9.2(b p)$ & 10 & 8 \\
\hline
\end{tabular}

Table 5. High-Pressure Infrared Spectroscopic Data ${ }^{a}$

\begin{tabular}{|c|c|c|c|c|}
\hline \multirow[b]{2}{*}{ ligand } & \multicolumn{2}{|c|}{ A-ee } & \multicolumn{2}{|c|}{ A-ea } \\
\hline & $v_{1}$ & $v_{3}$ & $v_{2}$ & $v_{4}$ \\
\hline $1 \mathbf{a}$ & $2039(\mathrm{~s})$ & $1974(s)$ & 1996(w) & 1949(w) \\
\hline $1 b$ & 2040(vs) & 1977(vs) & 1997(vw) & 1953(vw) \\
\hline 1c & 2043 & 1983 & & \\
\hline $2 a$ & $2049(\mathrm{~m})$ & 1979(m) & 1998(s) & $1950(\mathrm{~s})$ \\
\hline $2 b$ & & 1981(vw) & 1993(vs) & 1951(vs) \\
\hline \multicolumn{5}{|l|}{$2 c$} \\
\hline $3 a$ & $2022(\mathrm{~m})$ & 1971(m) & 1997(s) & 1956(s) \\
\hline $3 b$ & 2043(w) & 1985(w) & 1999(s) & 1959(s) \\
\hline $3 c$ & $2040(\mathrm{~m})$ & $1982(\mathrm{~m})$ & 1999(s) & 1954(s) \\
\hline \multicolumn{5}{|l|}{$4 a$} \\
\hline \multicolumn{5}{|l|}{$4 b$} \\
\hline \multicolumn{5}{|l|}{$4 c$} \\
\hline
\end{tabular}

(1:1), the formation of several rhodium complexes was observed. The observed structures are shown in Figure 3. The corresponding NMR data are summarized in Table 4, and the IR data are summarized in Table 5.

Despite the excess of ligand used, for all three xanthenebased ligands $\mathbf{1 a}-\mathbf{1 c}$, only the formation of the well-known $\mathrm{HRh}(\mathrm{L})(\mathrm{CO})_{2}$ structure $\mathbf{A}$ was observed. The coordination behavior of ligands 1a and $\mathbf{1 c}$ in structure $\mathbf{A}$ was previously reported. ${ }^{5 \mathrm{a}, 8 \mathrm{a}, \mathrm{b}}$ For ligand 1a, a mixture of structure A-ee and A-ea was observed in the high-pressure infrared experiments. Even at $-90{ }^{\circ} \mathrm{C}$, these two structures are in rapid equilibrium on the NMR time scale, yielding a single doublet in the ${ }^{31} \mathrm{P}$ NMR spectra and an averaged triplet of doublets for the hydride in the ${ }^{1} \mathrm{H}$ NMR spectra. Ligand 1c coordinates exclusively in a bisequatorial fashion in structure $\mathbf{A}$. No signals corresponding A-ea were observed in the highpressure IR spectra for this ligand system. Furthermore, the measured phosphine-hydride coupling constant was small, indicating a mutual cis arrangement of both phosphine moieties and the hydride ligand. Dissymmetric ligand $\mathbf{1 b}$ also exhibited predominantly bisequatorial coordination in structure $\mathbf{A}$, as was evidenced by the small ${ }^{2} J_{\mathrm{P}, \mathrm{H}}$ coupling constant observed in the hydride signal in the ${ }^{1} \mathrm{H}$ NMR spectra and the low intensities of the carbonyl absorptions corresponding to A-ea in the IR spectra.

$p$-Tolyl ether-based ligands $\mathbf{2 a}$ and $\mathbf{2 b}$ also showed exclusive formation of structure A under hydroformylation conditions. The NMR data collected for ligand 2a showed a considerably larger ${ }^{2} J_{\mathrm{P}, \mathrm{H}}$ coupling constant than the data collected for ligand 1a. This suggests that the equilibrium between A-ee and A-ea is shifted toward the equatorial-axial isomer A-ea. This was confirmed in the high-pressure IR experiments involving ligand $\mathbf{2} \mathbf{a}$, where the main absorptions were attributed to the equatorial-axial isomer of $\mathbf{A}$. Also for ligand $\mathbf{2} \mathbf{b}$, the main signals observed in the carbonyl region of the IR spectrum were attributed to the equatorial-axial isomer A-ea. Both the ${ }^{1} \mathrm{H}$ and ${ }^{31} \mathrm{P}\left\{{ }^{1} \mathrm{H}\right\}$ NMR data were consistent with an equatorial-axial coordination mode of the ligand in structure A. Proton-coupled ${ }^{31} \mathrm{P}$ NMR spectra revealed that the hydride coupled predominantly with the phosphorus signal at $29 \mathrm{ppm}$. On the basis of the phosphorus chemical shifts observed for ligands $\mathbf{2 a}$ and $\mathbf{2 c}$, this phosphorus signal is attributed to the diphenylphosphine moiety of ligand $\mathbf{2 b}$. Clearly, the diphenylphosphine moiety of ligand $\mathbf{2} \mathbf{b}$ is coordinated in the apical position of A-ea, trans toward the hydride moiety, and the phosphacyclic moiety is coordinated in the equatorial plane of structure A-ea.

The high-pressure NMR experiments involving ligand $\mathbf{2 c}$ showed not only the formation of structure $\mathbf{A}$ but also the formation of significant amounts of rhodium dimer $\mathbf{C}$, as well as smaller quantities of unidentified complexes. The high-pressure IR experiments, however, did not show the expected signals for structures $\mathbf{A}$ and $\mathbf{C}$. Instead, several absorptions in the terminal carbonyl region were observed, which could not be assigned on the basis of the available spectroscopic data.

As was previously reported for other ferrocene-based diphosphine ligands, ${ }^{5 b}$ reaction of $\mathrm{Rh}(\mathrm{acac})(\mathrm{CO})_{2}$ with an excess of $3 \mathbf{c}$ under an atmosphere of $\mathrm{H}_{2} / \mathrm{CO}$ at the high concentrations necessary for NMR spectroscopy yielded a mixture of dimeric structure $\mathbf{D}$ and monomeric structure $\mathbf{A}$. Due to the similar chemical shifts of all three phosphine moieties in structure D, highly complex second-order ${ }^{31} \mathrm{P}\left\{{ }^{1} \mathrm{H}\right\}$ NMR spectra are obtained for this complex at $0{ }^{\circ} \mathrm{C}$. 
Upon cooling the NMR sample, the signals broaden, indicative of fluxional behavior in this complex. Unfortunately, the limit of slow exchange could not be attained. Because of the absence of a coupling between the hydride signal and phosphine signals, and for steric reasons, we favor a structure of $\mathbf{D}$ in which the three phosphine moieties are predominantly coordinated in the equatorial plane of the complex. The observed fluxional behavior might indicate, however, that a rapid equilibrium exists between this major isomer and a minor one in which one of the phosphine moieties is coordinated in the axial position of the complex, trans to the hydride. Surprisingly, no formation of dimer $\mathbf{D}$ was observed for ligand $\mathbf{3 a}$ and dissymmetric ligand $\mathbf{3 b}$. Similar to ligand $\mathbf{2} \mathbf{b}$, ligand $\mathbf{3 b}$ showed the selective formation of A-ea, with the diphenylphosphine moiety predominantly occupying the axial position trans toward the hydride. For all three ferrocene-based ligands studied here, no signals originating from dimeric structure $\mathbf{D}$ could be observed in the high-pressure IR experiments. At the low rhodium concentration used in these IR experiments, the formation of monomeric structure $\mathbf{A}$ is strongly favored over the formation of dimer $\mathbf{D}$.

Under the high concentration conditions of the highpressure NMR experiments, benzene-based ligand $\mathbf{4 a}$ formed three major species. Next to species $\mathbf{A}$, dimer $\mathbf{C}$ and monomeric bischelate structure $\mathbf{B}$ were formed in significant quantities. The synthesis of bischelate complexes $\mathbf{B}$ has previously been reported for several ligands, ${ }^{27}$ including ligand 4a. ${ }^{28}$ James and co-workers showed that structure $\mathbf{B}$ containing either 1,2-bis(diphenylphosphino)ethane or 1,3bis(diphenylphosphino)propane ligands is quantitatively converted to dimer $\mathbf{C}$ under hydroformylation conditions, presumably via compound $\mathbf{A} .^{29}$ Also for ligand $\mathbf{4 a}$, we observed the slow conversion of $\mathbf{B}$ to dimer $\mathbf{C}$ in the highpressure NMR experiments.

Ligands $\mathbf{4 b}$ and $\mathbf{4} \mathbf{c}$ formed bischelate structure $\mathbf{B}$ selectively under the experimental conditions. For neither of them was formation of dimer $\mathbf{C}$ observed, not even after prolonged reaction times. For dissymmetric ligand $\mathbf{4 b}$, the hydride signal attributed to $\mathbf{B}$ was a doublet of triplets, consistent with fast fluxional processes within the complex. ${ }^{27 a}$ The coupling pattern suggests that the hydride couples with a single donor atom of each diphosphine ligand coordinated to the metal. Proton-coupled ${ }^{31}$ P NMR spectra were collected, and these revealed that the hydride couples solely with the phosphorus signal at $23.3 \mathrm{ppm}$. On the basis of the chemical shifts of the phosphine moieties in complexes $\mathbf{B}(\mathbf{4 a})$ and $\mathbf{B}(\mathbf{4 c})$, this signal was attributed to the phosphacyclic moiety of ligand $\mathbf{4 b}$. Upon cooling of the reaction mixture to $-60{ }^{\circ} \mathrm{C}$, both phosphine signals coalesced simultaneously. At $-80^{\circ} \mathrm{C}$, four broad signals are observed, indicating that in the absence of fast fluxional processes all four phosphorus moieties in complex $\mathbf{B}(\mathbf{4 b})$ become nonequivalent. The limit of slow exchange, however, could not be attained, not even

(27) (a) Meakin, P.; Muetterties, E. L.; Jesson, J. P. J. Am. Chem. Soc. 1972, 94, 5271. (b) Ball, R. G.; James, B. R.; Mahajan, D.; Trotter, J. Inorg. Chem. 1981, 20, 254. (c) Fryzuk, M. D. Can. J. Chem. 1983, 61, 1347. (d) Trzeciak, A. M.; Ziolkowski, J. J.; Aygen, S.; Eldik, R. v. J. Mol. Catal. 1986, 34, 337. (e) Castellanos-Paez, A.; Castillon, S.; Claver, C.; Van Leeuwen, P. W. N. M.; De Lange, W. G. J. Organometallics 1998, 17, 2543. (f) Rio, I. d.; De Lange, W. G. J.; Van Leeuwen, P. W. N. M.; Claver, C. J. Chem. Soc., Dalton Trans. 2001, 1293. (g) Raebiger, J. W.; DuBois, D. L. Organometallics 2005, 24, 110.

(28) Price, A. J.; Ciancanelli, R.; Noll, B. C.; Curtis, C. J.; DuBois, D. L.; DuBois, M. R. Organometallics 2002, 21, 4833.

(29) James, B.; Mahajan, D.; Rettig, S. J.; Williams, G. M. Organometallics 1983, 2, 1452. at $-90{ }^{\circ} \mathrm{C}$. For symmetrical bischelate complexes B containing either ligand $\mathbf{4 a}$ or $\mathbf{4 c}$ one sharp doublet was observed in the ${ }^{31} \mathrm{P}\left\{{ }^{1} \mathrm{H}\right\}$ NMR spectra, even at low temperatures. For these ligands, all four phosphine moieties are equivalent due to fast fluxional processes within the complex.

In contrast to the dimeric structures observed for ligands $\mathbf{2}$ and 3, which are formed only at high catalyst concentrations, the absence of strong carbonyl absorptions in the in situ IR spectra suggests that for ligands $\mathbf{4 a} \mathbf{- 4} \mathbf{c}$ bischelate species $\mathbf{B}$ is also the main species formed under catalytic conditions. Unfortunately, due to the low catalyst concentration and the relatively low resolution in the high-pressure IR experiments, the weak rhodium-hydride vibration band could not be observed for these compounds.

\section{Discussion}

The observed coordination behavior of ligands $\mathbf{1}-\mathbf{4}$ in rhodium structures $\mathbf{A}-\mathbf{D}$ under an atmosphere of $\mathrm{CO} / \mathrm{H}_{2}$ is consistent with previous high-pressure spectroscopic studies. Depending on the natural bite angle of the ligand, a bisequatorial and/or equatorial-axial coordination mode of the diphosphine ligand in structure $\mathbf{A}$ is observed. Xanthenebased ligands $\mathbf{1}$ show predominantly a bisequatorial coordination mode in species A. As was previously reported, introduction of 2,8-dimethylphenoxaphosphine moieties in ligands 1 led to an increase in the ratio A-ee:A-ea. ${ }^{14}$ This was attributed to the increased bite angle of $\mathbf{1 c}$ compared to $\mathbf{1 a}$ caused by steric repulsion between the two rigid phosphacyclic moieties in 1c. We also observe an increase in bite angle in the crystal structure of benzene-based ligand $\mathbf{4 c}$ compared to reported values for ligand $\mathbf{4 a},{ }^{17}$ but not in the calculated bite angles of ligands $\mathbf{2}-\mathbf{4}$ (Table 2).

The increase in the ratio of A-ee:A-ea upon introduction of phosphacyclic moieties in the ligand structure is not observed for $p$-tolyl ether and ferrocene-based ligands $\mathbf{2}$ and $\mathbf{3}$, which is in agreement with the calculated natural bite angles for these ligands. On the basis of the high flexibility of the ferrocene and $p$-tolyl ether backbones compared to the xanthene and benzene backbones, one would expect the bite angles of ligands $\mathbf{2}$ and $\mathbf{3}$ to be more sensitive to steric interactions between the two phosphine moieties than the bite angles of ligands 1 and $\mathbf{4}$. Probably, the high flexibility of the ferrocene and $p$-tolyl ether backbones permits reorientation of the rigid phenoxaphosphine moieties in structure Aea and so minimizes steric interactions between the two phosphine moieties of the ligand.

The NMR experiments show that the predominant coordination mode of ligands $\mathbf{2 b}$ and $\mathbf{3 b}$ in species $\mathbf{A}$ is equatorialaxial, their diphenylphosphine moieties coordinating in the axial position. Previous studies on equatorial-axial coordinating dissymmetric diphosphine ligands have shown that there is a strong preference for the coordination of the least basic moiety of the diphosphine ligand in the equatorial plane of complex A-ea, ${ }^{6 c}$ in accordance with simple orbital preferences. ${ }^{30}$ This confirms that 2,8-dimethylphenoxaphosphine moieties are indeed less basic than diphenylphosphine moieties. The lower basicity of the phenoxaphosphine moieties compared to the diphenylphosphine moieties in ligands $\mathbf{1 - 3}$ is also reflected by the increase in carbonyl stretching frequencies of species A-ee when the diphenylphosphine moieties of the ligands are replaced by phosphacyclic moieties (Table 5).

(30) Rossi, A. R.; Hoffmann, R. Inorg. Chem. 1975, 14, 365. 
These observations are in line with previous studies by our group on xanthene-based ligands $\mathbf{1 a}$ and $\mathbf{1 c} .^{4 a, 14}$ It should be noted that the bite angles of these two ligands differ significantly and that differences in the effective donor and acceptor properties of the two ligands might therefore arise from differences in bite angle. For the highly flexible ferrocene-based ligands 3 , we do not observe this change in bite angle upon introduction of 2,8-dimethylphenoxaphosphine moieties, and the increase in carbonyl stretching frequencies of species A-ee can only be attributed to the lower basicity of the phosphacyclic moieties in ligand $\mathbf{3 c}$ compared to the diphenylphosphine moieties of ligand 3a. Because of the presence of two carbonyl ligands and only a single phosphine moiety in the equatorial plane of complex A-ea, back-donation from the metal to the carbonyl ligands is expected to be less substantial in structure A-ea than in structure A-ee. Consequently, the carbonyl stretching frequencies of complex A-ea are less sensitive to variations in the basicity and $\pi$-acidity of the phosphine species.

For (small bite angle) benzene-based ligands 4, the formation of species A was not observed under hydroformylation conditions. Instead, the predominant species under catalytic conditions is bischelate compound $\mathbf{B}$. The geometry of structure $\mathbf{B}$ has previously been described as pseudotetrahedral, because the phosphorus ligands form a tetrahedral arrangement around the metal. The hydride moiety occupies one of the faces of this tetrahedron, resulting in a distorted trigonal-bipyramidal structure for $\mathbf{B} .^{27 \text { a }}$ For symmetrical ligands $\mathbf{4 a}$ and $\mathbf{4} \mathbf{c}$ all four phosphorus moieties interchange rapidly on the NMR time scale by movement of the hydride from one face to another via the edges of the tetrahedron. Surprisingly, similar studies on the coordination behavior of bidentate ligands containing two distinct donor moieties in structure $\mathbf{B}$ have not been reported. The high-pressure NMR data collected for complex $\mathbf{B}(\mathbf{4 b})$ suggest that the hydride is predominantly located trans toward the two phosphacyclic moieties of the complex. This is in sharp contrast with the coordination mode of ligands $\mathbf{2} \mathbf{b}$ and $\mathbf{3 b}$ in related species $\mathbf{A}$, where the most basic (diphenylphosphine) donor group is located trans toward the hydride. Here, the electronic preference for coordination of the least basic phosphine moiety in the equatorial plane of trigonal-bipyramidal rhodium structure $\mathbf{A}$ is overridden by steric interactions between the two diphosphine ligands in sterically congested complex $\mathbf{B}(\mathbf{4 b})$. Although we have shown that the introduction of phenoxaphosphine moieties in the ligand structure increases the steric hindrance between the two donor groups within the ligand (vide supra), the steric hindrance of the diphosphine ligand toward the other ligands in transition metal complexes actually decreases due to the planar structure of the phenoxaphosphine moiety (Table 2). Consequently, the diphenylphosphine moieties of both diphosphine ligands in complex $\mathbf{B}(\mathbf{4 b})$ are preferentially coordinated in the equatorial plane of the distorted trigonal-bipyramidal complex, minimizing steric repulsion between the two bidentate ligands in this highly congested structure.

In some instances, the differences in catalytic activity and selectivity can be correlated to the results obtained from the in situ spectroscopic studies. Since xanthene-based ligands 1a-1c all exhibit mainly bisequatorial coordination in structure $\mathbf{A}$, it is not surprising that dissymmetric ligand $\mathbf{1 b}$ shows rates of aldehyde formation and alkene isomerization that are an average of the values obtained for symmetrical ligands 1a and 1c. Also for ligands $\mathbf{2}$ and $\mathbf{3}$ we observe an increase in the rate of hydroformylation upon introduction of phosphacyclic moieties. Both the decreased electron density at the metal center and reduced steric hindrance around the rhodium center induced by these cyclic structures should favor the coordination of the more bulky and more electrondonating alkene ligand over the electron-withdrawing and nonbulky carbon monoxide ligand and, so, will shift the equilibrium that exists between the carbon monoxide complex and the alkene complex toward the latter. Moreover, it has been shown that electron-withdrawing ligands facilitate the subsequent rate-limiting hydride migration step. ${ }^{31}$ Therefore, both the decreased donor strength and reduced steric bulk of these cyclic ligands enhance the overall activity of the rhodium catalyst in the hydroformylation reaction.

Using different isosteric diphosphine ligands several authors have previously shown that the linear over branched ratio of the aldehyde products formed in the reaction is influenced by the electronic properties of the ligands used in the reaction. Casey and co-workers showed that decreasing the $\sigma$-donating properties of the equatorial phosphine moieties in structure A leads to an increase in the 1/b ratio, while decreasing the $\sigma$-donating properties of the axial phosphorus moiety in structure A-ea decreases the $1 / \mathrm{b}$ ratio. ${ }^{6 \mathrm{~b}, \mathrm{c}} \mathrm{We}$ have shown that for wide bite angle ligands the percentage of linear aldehyde formed is largely independent of the electronic properties of the diphosphine ligand. The observed increase in $1 / \mathrm{b}$ ratio for less basic diphosphine ligands was attributed to an increase in the rate of alkene isomerization during the hydroformylation process. ${ }^{5 \mathrm{a}, 14}$ For ligands $\mathbf{1 - 4}$, however, we observe a decrease in both the $1 / \mathrm{b}$ ratio and the percentage of linear aldehyde formed when the less basic phosphacyclic moieties are used instead of diphenylphosphine moieties, despite the increase in the rate of alkene isomerization. We attribute this decrease in regioselectivity to the large steric differences between the diphenylphosphine and 2,8-dimethylphenoxaphosphine moieties, which outweigh the smaller electronic differences between the two moieties.

Direct comparison of the catalytic activities of benzenebased ligands $\mathbf{4}$ to those of the other ligands used in this study is hampered by the quantitative formation of bischelate species $\mathbf{B}$ under the reaction conditions. For these ligands, the generation of a catalytically active species will require dissociation of one of the diphosphine ligands from species B. Therefore, the catalytic activity of catalyst systems containing ligands $\mathbf{4}$ is highly dependent on the stability of species $\mathbf{B}$ and the rhodium and ligand concentrations under experimental conditions. The high-pressure NMR spectroscopic results show that, while for ligand $\mathbf{4 a}$ species $\mathbf{B}$ is converted to catalytically active species $\mathbf{A}$ and dimer $\mathbf{C}$, compound $\mathbf{B}$ is stable for ligands $\mathbf{4 b}$ and $\mathbf{4 c}$ under identical conditions. The stability of species $\mathbf{B}$ relative to catalytically active species $\mathbf{A}$ is enhanced by both the lower basicity and reduced steric hindrance of the phenoxaphosphine-containing ligands $\mathbf{4 b}$ and $\mathbf{4} \mathbf{c}$ compared to the diphenylphosphinebased ligand $\mathbf{4 a}$. It is therefore not surprising that for ligand $\mathbf{4 c}$, present in excess, the high stability of structure $\mathbf{B}$ under $\mathrm{H}_{2} / \mathrm{CO}$ atmosphere leads to an inactive catalyst system for hydroformylation of 1-octene.

(31) (a) Zuidema, E.; Daura-Oller, E.; Carbo, J. J.; Bo, C.; Van Leeuwen, P. W. N. M. Organometallics 2007, 26, 2234. (b) Zuidema, E.; Escorihuela, L.; Echelsheim, T.; Carbo, J. J.; Bo, C.; Kamer, P. C. J.; Van Leeuwen, P. W. N. M. Chem.-Eur. J. 2008, 14, 1843. 


\section{Conclusions}

We have synthesized a series of new bidentate phosphine ligands based on 2,2'-p-tolyl ether, 1,1'-ferrocene, and 1,2benzene ligand backbones containing one or two 2,8-dimethylphenoxaphosphine phosphacyclic moieties. The ligands were employed in the hydroformylation of 1-octene, and their coordination behavior under hydroformylation conditions was studied using high-pressure spectroscopic techniques. Both the catalytic and high-pressure spectroscopic data clearly illustrate the distinct electronic and steric properties of the diphenylphosphine- and 2,8-dimethylphenoxaphosphine-modified diphosphine ligands.

High-pressure spectroscopic studies on ligands incorporating both a phenoxaphosphine and a diphenylphosphine moiety $(\mathbf{1 b}-\mathbf{4 b})$ show that phenoxaphosphine moieties are less basic than diphenylphosphine donor moieties. Although introduction of phenoxaphosphine moieties increases the steric hindrance between the two donor moieties of the diphosphine ligand, it decreases the steric hindrance imposed by the diphosphine ligand toward other ligands in transition metal complexes. Both the lower basicity and lower steric bulk of phenoxaphosphine-modified ligands facilitate carbon monoxide-alkene exchange and the key hydride migration in the hydroformylation catalytic cycle, leading to an increase in the overall rate of hydroformylation for the phosphacyclic ligands. The lower regioselectivity in the hydroformylation of 1-octene observed for these phosphacyclic ligands is also consistent with the decreased steric interaction between the diphosphine ligand and the alkene substrate during the hydroformylation reaction.

\section{Experimental Section}

5.1. General Remarks. All reactions were carried out using standard Schlenk techniques under an atmosphere of purified argon, unless stated otherwise. Toluene was distilled from sodium, THF and diethyl ether were distilled from sodium/benzophenone, and hexanes and $n$-pentane were distilled from sodium/benzophenone/triglyme. Dichloromethane and all deuterated solvents were distilled from $\mathrm{CaH}_{2}$. Chemicals were purchased from Aldrich Chemical Company and Acros Chimica. 2,2'-Dibromo- $p$-tolyl ether, ${ }^{32} 2,2^{\prime}$-bis(diphenylphosphino)-p-tolyl ether, 2,8-dimethylphenoxaphosphine chloride, ${ }^{8 c, 33}$ (2-bromophenyl)(diphenyl)phosphine, ${ }^{20,34}$ 1-bromo-1'-diphenylphosphinoferrocene, ${ }^{19}$ bis(diphenylphosphino)-2,7-di-tert-butyl-9,9-dimethylxanthene, ${ }^{8 \mathrm{a}, \mathrm{b}}$ and $\operatorname{bis}(2$, 8-dimethylphenoxaphosphino)-2,7-di-tert-butyl-9,9-dimethylxanthene $\mathrm{e}^{8 \mathrm{a}, \mathrm{b}, 14}$ were synthesized according to previously published procedures.

5.2. Computational Details. Natural bite angle calculations were performed with CaChe WorkSystem 6.1 using a modified MM3 force field. A methodology similar to the one described by Casey and Whiteker was employed. ${ }^{2}$ The rhodium - phosphorus equilibrium distance was set to $2.315 \AA$, and the corresponding force constant was set to 1000 . The phosphorus-rhodiumphosphorus angle was set to $180^{\circ}$, and its force constant was set to 0.0 . Energy minimizations were performed using the blockdiagonal Newton-Raphson method, applying a geometry convergence criterion of $0.0001 \mathrm{kcal}^{-1} \AA^{-1}$.

Solid angles ${ }^{22}$ of the MM3-optimized structures were determined using the Steric program, ${ }^{23}$ developed by Taverner and

(32) Okawa, H.; Koyama, H.; Inazu, T.; Yoshino, T. Bull. Chem. Soc. Jpn. 1970, 43, 1729 .

(33) Herwig, J.; Bohnen, H.; Skutta, P.; Sturm, S.; Van Leeuwen, P. W. N. M.; Bronger, R. P. J. WO 2002068434, 2002.

(34) Baillie, C.; Xiao, J. Tetrahedron 2004, 60, 4159. co-workers. Solid angles were calculated by projecting the ligands onto a sphere centered at the rhodium atom. The solid angles were expressed as the percentage of the sphere covered by the ligand projection. The solid angle calculations were performed using the Craig algorithm, which takes into account multiple overlaps in the projection of the ligand onto the sphere.

5.3. Ligand Synthesis. 1-(Bis(diethylamino)phosphino)-2bromobenzene (5). To a solution of $1 \mathrm{~mL}$ of 1,2-dibromobenzene $(8.3 \mathrm{mmol})$ in $100 \mathrm{~mL}$ of a 1:1:1 mixture of THF, pentane, and diethyl ether was added dropwise $3.3 \mathrm{~mL}$ of a $2.5 \mathrm{M}$ solution of $n$-butyllithium $(8.25 \mathrm{mmol})$ at $-120^{\circ} \mathrm{C}$. The solution was stirred for $15 \mathrm{~min}$. Subsequently, $1.75 \mathrm{~g}(8.3 \mathrm{mmol})$ of bis(diethylamino)phosphine chloride dissolved in $15 \mathrm{~mL}$ of a $1: 1: 1$ mixture of THF, pentane, and diethyl ether was added dropwise to the reaction mixture. The resulting mixture was stirred overnight, allowing the temperature of the mixture to rise to room temperature. The solvents were removed in vacuo. The resulting yellow oil was dissolved in dichloromethane and purified using flash column chromatography over neutral alumina. Evaporation of the solvent yields $1.35 \mathrm{~g}(4.1 \mathrm{mmol}, 49 \%)$ of a colorless, air-sensitive oil: ${ }^{1} \mathrm{H}$ NMR $\left(\mathrm{CDCl}_{3}\right) \delta(\mathrm{ppm}), 1.09\left(\mathrm{t},{ }^{3} J_{\mathrm{H}, \mathrm{H}}=\right.$ $7.3 \mathrm{~Hz}, 12 \mathrm{H}), 3.08(\mathrm{~m}, 8 \mathrm{H}), 7.07\left(\mathrm{t},{ }^{3} J_{\mathrm{H}, \mathrm{H}}=6.1 \mathrm{~Hz}, 1 \mathrm{H}\right), 7.26(\mathrm{t}$, $\left.{ }^{3} J_{\mathrm{H}, \mathrm{H}}=6.1 \mathrm{~Hz}, 1 \mathrm{H}\right), 7.47(\mathrm{bs}, 1 \mathrm{H}), 7.50(\mathrm{~m}, 1 \mathrm{H}) ;{ }^{31} \mathrm{P}\left\{{ }^{1} \mathrm{H}\right\} \mathrm{NMR}$ $\left(\mathrm{CDCl}_{3}\right) \delta(\mathrm{ppm}), 95.8(\mathrm{~s}) ;{ }^{13} \mathrm{C}\left\{{ }^{1} \mathrm{H}\right\} \mathrm{NMR}\left(\mathrm{CDCl}_{3}\right) \delta(\mathrm{ppm}), 15.2$ $(\mathrm{s}), 43.9\left(\mathrm{~d},{ }^{2} J_{\mathrm{C}, \mathrm{P}}=18 \mathrm{~Hz}\right), 127.0(\mathrm{~s}), 127.3(\mathrm{~s}), 129.3(\mathrm{~s}), 132.5(\mathrm{~d}$, $\left.{ }^{2} J_{\mathrm{C}, \mathrm{P}}=6 \mathrm{~Hz}\right), 133.7(\mathrm{~s}), 147.6\left(\mathrm{~d},{ }^{1} J_{\mathrm{C}, \mathrm{P}}=11 \mathrm{~Hz}\right)$; exact mass $(\mathrm{FAB}+)$ calcd for $\mathrm{C}_{14} \mathrm{H}_{25} \mathrm{~N}_{2} \mathrm{BrP}(\mathrm{M}+\mathrm{H}) 331.0939$, found 331.0939. Anal. Calcd for $\mathrm{BrC}_{14} \mathrm{H}_{24} \mathrm{~N}_{2} \mathrm{P}: \mathrm{C}, 50.77 ; \mathrm{H}, 7.30 ; \mathrm{N}$, 8.46. Found: $\mathrm{C}, 50.86 ; \mathrm{H}, 7.35 ; \mathrm{N}, 8.53$.

1-(2,8-Dimethylphenoxaphosphino)-2-(bis(diethylamino)phosphino)benzene (6). To a solution of $2.0 \mathrm{~g}$ of 1-(bis(diethylamino)phosphino)-2-bromobenzene (5) $(6.0 \mathrm{mmol})$ in $40 \mathrm{~mL}$ of diethyl ether was added dropwise $2.8 \mathrm{~mL}$ of a $2.35 \mathrm{M}$ solution of $n$-butyllithium $(6.6 \mathrm{mmol})$ at $-80{ }^{\circ} \mathrm{C}$. The reaction mixture was stirred at $-80{ }^{\circ} \mathrm{C}$ for one hour and one additional hour at $0{ }^{\circ} \mathrm{C}$. The dark red solution was cooled to $-80^{\circ} \mathrm{C}$, and a solution of $1.8 \mathrm{~g}$ of 2,8-dimethylphenoxaphosphine chloride $(6.9 \mathrm{mmol})$ in $20 \mathrm{~mL}$ of THF was added dropwise. The resulting suspension was stirred overnight, during which the solution was allowed to warm to room temperature. The solvents were removed in vacuo, and the product was purified using flash column chromatography over basic alumina (eluent: dichloromethane). Recrystallization of the solid from cold $n$-hexane yielded $1.9 \mathrm{~g}$ of white crystals $(3.9 \mathrm{mmol}, 65 \%):{ }^{1} \mathrm{H}$ NMR $\left(\mathrm{CDCl}_{3}\right) \delta(\mathrm{ppm}) 1.16(\mathrm{t}$, $\left.{ }^{3} J_{\mathrm{H}, \mathrm{H}}=7.2 \mathrm{~Hz}, 12 \mathrm{H}\right), 2.03(\mathrm{~s}, 6 \mathrm{H}), 3.20(\mathrm{~m}, 8 \mathrm{H}), 7.02(\mathrm{~d}$, $\left.{ }^{3} J_{\mathrm{H}, \mathrm{H}}=8.1 \mathrm{~Hz}, 2 \mathrm{H}\right), 7.07(\mathrm{~m}, 4 \mathrm{H}), 7.20\left(\mathrm{t},{ }^{3} J_{\mathrm{H}, \mathrm{H}}=7.2 \mathrm{~Hz}, 1 \mathrm{H}\right)$, $7.32\left(\mathrm{bd},{ }^{3} J_{\mathrm{H}, \mathrm{H}}=9.6 \mathrm{~Hz}, 2 \mathrm{H}\right), 7.55(\mathrm{~m}, 1 \mathrm{H}) ;{ }^{31} \mathrm{P}\left\{{ }^{1} \mathrm{H}\right\} \mathrm{NMR}$ $\left(\mathrm{CDCl}_{3}\right) \delta(\mathrm{ppm})-58.9\left(\mathrm{~d},{ }^{3} J_{\mathrm{P}, \mathrm{P}}=126 \mathrm{~Hz}\right), 95.1\left(\mathrm{~d},{ }^{3} J_{\mathrm{P}, \mathrm{P}}=126\right.$ $\mathrm{Hz}) ;{ }^{13} \mathrm{C}\left\{{ }^{1} \mathrm{H}\right\} \mathrm{NMR}\left(\mathrm{CDCl}_{3}\right) \delta(\mathrm{ppm}), 15.1(\mathrm{~s}), 20.5$ (s), 44.1 (s), $117.8(\mathrm{~s}), 119.9\left(\mathrm{dd},{ }^{1} J_{\mathrm{C}, \mathrm{P}}=9 \mathrm{~Hz},{ }^{2} J_{\mathrm{C}, \mathrm{P}}=4 \mathrm{~Hz}\right), 128.7(\mathrm{~d}$, $\left.{ }^{1} J_{\mathrm{C}, \mathrm{P}}=17 \mathrm{~Hz}\right), 130.2(\mathrm{~m}), 130.9(\mathrm{~s}), 132.8\left(\mathrm{~d},{ }^{1} J_{\mathrm{C}, \mathrm{P}}=10 \mathrm{~Hz}\right)$, 134.5 (bs), $135.1\left(\mathrm{dd},{ }^{1} J_{\mathrm{C}, \mathrm{P}}=32 \mathrm{~Hz},{ }^{2} J_{\mathrm{C}, \mathrm{P}}=5 \mathrm{~Hz}\right), 144.1(\mathrm{~s})$, $144.3(\mathrm{~d}, J=29 \mathrm{~Hz}), 148.0\left(\mathrm{dd},{ }^{1} J_{\mathrm{C}, \mathrm{P}}=31 \mathrm{~Hz},{ }^{2} J_{\mathrm{P}, \mathrm{C}}=16 \mathrm{~Hz}\right)$, 153.8 (s). Anal. Calcd for $\mathrm{C}_{28} \mathrm{H}_{36} \mathrm{~N}_{2} \mathrm{OP}_{2}$ : C, 70.28; H, 7.58; N, 5.85. Found: C, 70.39; H, 7.69; N, 5.74.

1-(2,8-Dimethylphenoxaphosphino)-2-(dichlorophosphino)benzene (7). $120 \mathrm{mg}$ of 1-(2,8-dimethylphenoxaphosphino)-2-(bis(diethylamino)phosphino)benzene (6) (0.25 mmol) was dissolved at $0{ }^{\circ} \mathrm{C}$ in $1.0 \mathrm{~mL}$ of $\mathrm{PCl}_{3}$. The solution was heated to $50{ }^{\circ} \mathrm{C}$ for $2 \mathrm{~h}$. The solvents were removed in vacuo, and the resulting solid was extracted using $2 \times 2 \mathrm{~mL}$ of diethyl ether. Evaporation of the solvents yielded $85 \mathrm{mg}$ of a highly air- and moisture-sensitive white solid $(0.21 \mathrm{mmol}, 84 \%)$, which was recrystallized from $n$-hexane. ${ }^{1} \mathrm{H}$ NMR $\left(\mathrm{CDCl}_{3}\right) \delta(\mathrm{ppm}), 2.27(\mathrm{~s}, 6 \mathrm{H}), 7.10\left(\mathrm{~d},{ }^{3} J_{\mathrm{H}, \mathrm{H}}=8.7 \mathrm{~Hz}\right.$, $2 \mathrm{H}), 7.17\left(\mathrm{dd},{ }^{3} J_{\mathrm{H}, \mathrm{H}}=8.7 \mathrm{~Hz},{ }^{4} J_{\mathrm{H}, \mathrm{H}}=1.8 \mathrm{~Hz}, 2 \mathrm{H}\right), 7.24(\mathrm{~m}, 3 \mathrm{H})$, $7.31\left(\mathrm{dd},{ }^{3} J_{\mathrm{H}, \mathrm{H}}=7.8 \mathrm{~Hz},{ }^{4} J_{\mathrm{H}, \mathrm{H}}=1.5 \mathrm{~Hz}, 1 \mathrm{H}\right), 7.44\left(\mathrm{dd},{ }^{3} J_{\mathrm{H}, \mathrm{H}}=\right.$ $\left.7.8 \mathrm{~Hz},{ }^{3} J_{\mathrm{H}, \mathrm{H}}=7.2 \mathrm{~Hz}, 1 \mathrm{H}\right), 8.19(\mathrm{~m}, 1 \mathrm{H}) ;{ }^{31} \mathrm{P}\left\{{ }^{1} \mathrm{H}\right\} \mathrm{NMR}\left(\mathrm{CDCl}_{3}\right)$ $\delta(\mathrm{ppm}),-66.8\left(\mathrm{~d},{ }^{3} J_{\mathrm{P}, \mathrm{P}}=344 \mathrm{~Hz}\right), 160.5\left(\mathrm{~d},{ }^{3} J_{\mathrm{P}, \mathrm{P}}=344 \mathrm{~Hz}\right)$; ${ }^{13} \mathrm{C}\left\{{ }^{1} \mathrm{H}\right\} \operatorname{NMR}\left(\mathrm{CDCl}_{3}\right) \delta(\mathrm{ppm}), 20.8(\mathrm{~s}), 116.5\left(\mathrm{~d},{ }^{1} J_{\mathrm{C}, \mathrm{P}}=9 \mathrm{~Hz}\right)$, $130.4\left(\mathrm{dd},{ }^{1} J_{\mathrm{C}, \mathrm{P}}=9 \mathrm{~Hz},{ }^{2} J_{\mathrm{C}, \mathrm{P}}=3.6 \mathrm{~Hz}\right), 130.6(\mathrm{~s}), 132.3(\mathrm{~s}), 133.3$ 
$\left(\mathrm{d},{ }^{1} J_{\mathrm{C}, \mathrm{P}}=28 \mathrm{~Hz}\right), 133.6(\mathrm{~s}), 134.8(\mathrm{~s}), 134.8\left(\mathrm{~d},{ }^{1} J_{\mathrm{C}, \mathrm{P}}=31 \mathrm{~Hz}\right)$, $145.0\left(\mathrm{~d},{ }^{1} J_{\mathrm{C}, \mathrm{P}}=32 \mathrm{~Hz}\right), 145.3\left(\mathrm{dd}, 1 J_{\mathrm{C}, \mathrm{P}}=31 \mathrm{~Hz},{ }^{2} J_{\mathrm{C}, \mathrm{P}}=6 \mathrm{~Hz}\right)$, $146.0\left(\mathrm{~d},{ }^{1} J_{\mathrm{C}, \mathrm{P}}=31 \mathrm{~Hz}\right), 155.6(\mathrm{~s})$.

2-Bromo-2'-(2,8-dimethylphenoxaphosphino)p-tolyl Ether (8). To a solution of $3.0 \mathrm{~g}$ of $2,2^{\prime}$-dibromo- $p$-tolyl ether $(8.4 \mathrm{mmol})$ in $50 \mathrm{~mL}$ of diethyl ether was added dropwise $3.5 \mathrm{~mL}$ of a $2.4 \mathrm{M}$ solution of $n$-butyllithium $(8.4 \mathrm{mmol})$ at $-80{ }^{\circ} \mathrm{C}$. The solution was stirred for $30 \mathrm{~min}$. Subsequently, $2.23 \mathrm{~g}$ of 2,8-dimethylphenoxyphosphine chloride $(8.5 \mathrm{mmol})$ suspended in $30 \mathrm{~mL}$ of THF was added to the solution. The resulting mixture was stirred overnight, allowing the temperature to rise to room temperature. The solvents were removed in vacuo, and the resulting sticky solid was dissolved in $50 \mathrm{~mL}$ of dichloromethane. Then $40 \mathrm{~mL}$ of degassed water was added to the mixture. The organic layer was separated, and the water layer was extracted with $2 \times 20 \mathrm{~mL}$ of dichloromethane. The combined organic layers were dried using $\mathrm{MgSO}_{4}$. Removal of the solvent in vacuo yielded a light yellow solid. The product was recrystallized from dichloromethane/methanol, yielding $5.2 \mathrm{~g}$ of colorless needles $(5.0 \mathrm{mmol}, 62 \%)$ : ${ }^{1} \mathrm{H}$ NMR (toluene- $d_{8}$ ) $\delta(\mathrm{ppm}), 2.11(\mathrm{~s}, 3 \mathrm{H}), 2.26(\mathrm{~s}, 6 \mathrm{H}), 2.31(\mathrm{~s}, 3 \mathrm{H}), 6.43\left(\mathrm{~d},{ }^{3} J_{\mathrm{H}, \mathrm{H}}\right.$ $=12.1 \mathrm{~Hz}, 1 \mathrm{H}), 6.52(\mathrm{~m}, 2 \mathrm{H}), 6.94\left(\mathrm{~d},{ }^{3} J_{\mathrm{H}, \mathrm{H}}=7.9 \mathrm{~Hz}, 2 \mathrm{H}\right), 7.07$ $\left(\mathrm{d},{ }^{3} J_{\mathrm{H}, \mathrm{H}}=7.9 \mathrm{~Hz}, 2 \mathrm{H}\right), 7.15\left(\mathrm{~d},{ }^{3} J_{\mathrm{H}, \mathrm{H}}=7.9 \mathrm{~Hz}, 2 \mathrm{H}\right), 7.42(\mathrm{bd}$, $\left.{ }^{3} J_{\mathrm{H}, \mathrm{H}}=12.1 \mathrm{~Hz}\right), 7.46(\mathrm{bs}, 1 \mathrm{H}) ;{ }^{31} \mathrm{P}\left\{{ }^{1} \mathrm{H}\right\}$ NMR (toluene- $d_{8}$ ) $\delta(\mathrm{ppm}),-64.8(\mathrm{~s}) ;{ }^{13} \mathrm{C}\left\{{ }^{1} \mathrm{H}\right\}$ NMR (toluene- $\left.d_{8}\right) \delta(\mathrm{ppm}), 20.7(\mathrm{~s})$, $20.8(\mathrm{~s}), 21.1(\mathrm{~s}), 114.0(\mathrm{~s}), 117.2(\mathrm{~s}), 117.6(\mathrm{~s}), 117.9(\mathrm{~s}), 129.3(\mathrm{~s})$, $130.3(\mathrm{~s}), 130.6\left(\mathrm{~d},{ }^{1} J_{\mathrm{C}, \mathrm{P}}=26 \mathrm{~Hz}\right), 131.0(\mathrm{~s}), 131.9(\mathrm{~s}), 132.9(\mathrm{~d}$, $\left.{ }^{1} J_{\mathrm{C}, \mathrm{P}}=12 \mathrm{~Hz}\right), 133.2(\mathrm{~s}), 133.4(\mathrm{~s}), 134.0(\mathrm{~s}), 134.5(\mathrm{~s}), 136.0(\mathrm{~s})$, 136.5 (s), 152.1 (s), $154.9(\mathrm{~s}), 156.5\left(\mathrm{~d},{ }^{1} J_{\mathrm{C}, \mathrm{P}}=16 \mathrm{~Hz}\right)$; exact mass $(\mathrm{FAB}+)$ calcd for $\mathrm{C}_{28} \mathrm{H}_{25} \mathrm{BrO}_{2} \mathrm{P}(\mathrm{M}+\mathrm{H})$ 503.0776, found 503.0780. Anal. Calcd for $\mathrm{C}_{28} \mathrm{H}_{24} \mathrm{BrO}_{2} \mathrm{P}$ : C, 66.81; H, 4.81. Found: C, 66.68; H, 4.90 .

4-Bromo-2,7-di-tert-butyl-9,9-dimethyl-5-diphenylphosphinoxanthene (9). This compound was synthesized using a modified literature procedure. ${ }^{8 \mathrm{a}, \mathrm{b}}$ To a solution of $5.0 \mathrm{~g}$ of 4,5-dibromo2,7-di-tert-butyl-9,9-dimethylxanthene (10.4 mmol) in $120 \mathrm{~mL}$ of THF was added dropwise $4.3 \mathrm{~mL}$ of a $2.4 \mathrm{M}$ solution of $n$-butyllithium $(10.4 \mathrm{mmol})$ at $-80^{\circ} \mathrm{C}$. The solution was stirred for $2 \mathrm{~h}$. Subsequently, $1.9 \mathrm{~mL}$ of chlorodiphenylphosphine (10.5 mmol) in $25 \mathrm{~mL}$ of hexanes was added dropwise to the solution. The resulting mixture was stirred at $-80{ }^{\circ} \mathrm{C}$ for one hour and was subsequently allowed to warm to room temperature overnight. The mixture was hydrolyzed using a $1.0 \mathrm{M}$ solution of $\mathrm{HCl}$ in water and extracted three times with $60 \mathrm{~mL}$ of dichloromethane. The combined organic layers were dried using $\mathrm{MgSO}_{4}$. Removal of the solvent in vacuo yielded a light yellow solid. The product was recrystallized from dichloromethane/methanol, yielding $3.7 \mathrm{~g}$ of colorless needles $(6.4 \mathrm{mmol}$, $62 \%):{ }^{1} \mathrm{H} \mathrm{NMR}\left(\mathrm{CDCl}_{3}\right) \delta(\mathrm{ppm}), 1.15(\mathrm{~s}, 9 \mathrm{H}), 1.32(\mathrm{~s}, 9 \mathrm{H}), 1.75(\mathrm{~s}$, $6 \mathrm{H}), 6.54\left(\mathrm{dd},{ }^{3} J_{\mathrm{P}, \mathrm{H}}=4.4 \mathrm{~Hz},{ }^{4} J_{\mathrm{H}, \mathrm{H}}=2.4 \mathrm{~Hz}\right), 7.35(\mathrm{~m}, 13 \mathrm{H})$; ${ }^{31} \mathrm{P}\left\{{ }^{1} \mathrm{H}\right\}$ NMR $\left(\mathrm{CDCl}_{3}\right) \delta(\mathrm{ppm}),-13.5(\mathrm{~s}) ;{ }^{13} \mathrm{C}\left\{{ }^{1} \mathrm{H}\right\}$ NMR $\left(\mathrm{CDCl}_{3}\right) \delta(\mathrm{ppm}), 31.2(\mathrm{~s}), 31.4(\mathrm{~s}), 32.3(\mathrm{~s}), 34.6(\mathrm{~s}), 35.5(\mathrm{~s})$, $121.6(\mathrm{~s}), 123.1(\mathrm{~s}), 125.0\left(\mathrm{~d},{ }^{1} J_{\mathrm{P}, \mathrm{C}}=15 \mathrm{~Hz}\right), 128.5(\mathrm{~s}), 128.7(\mathrm{~d}$, $\left.{ }^{2} J_{\mathrm{P}, \mathrm{C}}=28 \mathrm{~Hz}\right), 129.1(\mathrm{~s}), 131.1(\mathrm{~s}), 134.0(\mathrm{~s}), 134.8(\mathrm{~s}), 136.4(\mathrm{~d}$, $\left.{ }^{1} J_{\mathrm{P}, \mathrm{C}}=11 \mathrm{~Hz}\right), 145.0(\mathrm{~s}), 145.6(\mathrm{~s}), 146.8(\mathrm{~s}), 150.1\left(\mathrm{~d},{ }^{2} J_{\mathrm{P}, \mathrm{C}}=\right.$ $15 \mathrm{~Hz})$; exact mass $(\mathrm{FAB}+)$ calcd for $\mathrm{C}_{35} \mathrm{H}_{39} \mathrm{BrOP}(\mathrm{M}+\mathrm{H})$ 587.1908, found 587.1919. Anal. Calcd for $\mathrm{C}_{35} \mathrm{H}_{38} \mathrm{BrOP}$ : C, 71.79; H, 6.55. Found: C, 71.58; H, 6.59.

4-(2,8-Dimethylphenoxaphosphino)-5-(diphenylphosphino)2,7-di-tert-butyl-9,9-dimethylxanthene (1b). This compound was synthesized using a modified literature procedure. ${ }^{8 \mathrm{a}, \mathrm{b}}$ To a solution of $2.0 \mathrm{~g}$ of 4-bromo-2,7-di-tert-butyl-9,9-dimethyl-5-diphenylphosphinoxanthene (9) $(3.5 \mathrm{mmol})$ in $50 \mathrm{~mL}$ of THF was added dropwise $1.5 \mathrm{~mL}$ of a $2.4 \mathrm{M}$ solution of $n$-butyllithium $(3.6 \mathrm{mmol})$ at $-80{ }^{\circ} \mathrm{C}$. The resulting solution was stirred at $-80{ }^{\circ} \mathrm{C}$ for one hour, after which $1.0 \mathrm{~g}$ of 2,8 dimethylphenoxaphosphine chloride $(3.8 \mathrm{mmol})$ suspended in $25 \mathrm{~mL}$ of THF was added dropwise. The reaction mixture was stirred overnight, allowing the solution to warm slowly to room temperature. The solvents were removed in vacuo, and the resulting solid was redissolved in $60 \mathrm{~mL}$ of dichloromethane. The mixture was washed using $30 \mathrm{~mL}$ of a degassed $1 \mathrm{M}$ aqueous $\mathrm{HCl}$ solution. The organic layer was separated and dried using $\mathrm{MgSO}_{4}$. The solvents were removed in vacuo, and the resulting solid was recrystallized from dichloromethane/methanol, yielding $1.83 \mathrm{~g}$ of colorless crystals $(2.5 \mathrm{mmol}, 70 \%):{ }^{1} \mathrm{H}$ NMR $\left(\mathrm{CDCl}_{3}\right) \delta(\mathrm{ppm}) 1.03(\mathrm{~s}$, $9 \mathrm{H}), 1.15(\mathrm{~s}, 9 \mathrm{H}), 1.60(\mathrm{~s}, 6 \mathrm{H}), 2.21(\mathrm{~s}, 6 \mathrm{H}), 7.02\left(\mathrm{~d},{ }^{3} J_{\mathrm{H}, \mathrm{H}}=\right.$ $8.2 \mathrm{~Hz}, 2 \mathrm{H}), 7.08\left(\mathrm{dd},{ }^{3} J_{\mathrm{H}, \mathrm{H}}=8.2 \mathrm{~Hz},{ }^{4} J_{\mathrm{H}, \mathrm{H}}=2.4 \mathrm{~Hz}\right), 7.21$ $\left(\mathrm{d},{ }^{4} J_{\mathrm{H}, \mathrm{H}}=2.4 \mathrm{~Hz}\right), 7.4-7.5(\mathrm{~m}, 13 \mathrm{H}) ;{ }^{31} \mathrm{P}\left\{{ }^{1} \mathrm{H}\right\}$ NMR $(\mathrm{CDCl}) \delta(\mathrm{ppm}),-70.9\left(\mathrm{~d}, J_{\mathrm{P}, \mathrm{P}}=26 \mathrm{~Hz}\right),-15.3\left(\mathrm{~d}, J_{\mathrm{P}, \mathrm{P}}=\right.$ $26 \mathrm{~Hz}) ;{ }^{13} \mathrm{C}\left\{{ }^{1} \mathrm{H}\right\} \mathrm{NMR}\left(\mathrm{CDCl}_{3}\right) \delta(\mathrm{ppm}) 20.9(\mathrm{~s}), 21.4(\mathrm{~s}), 34.1$ (s), $34.4(\mathrm{~s}), 112.3$ (s), 115.4 (s), 117.2 (s), 117.8 (s), 118.9 (s), 119.2 (s), 127.3 (s), 128.4 (s), 129.3 (s), 130.9 (s), 131.6 (s), 131.9 (s), 132.5 (s), 132.7 (s), 132.9 (s), 133.5 (s), 134.3 (s), 134.5 (s), 136.0 (s), 136.4 (s), $137.8\left(\mathrm{~d},{ }^{1} J_{\mathrm{C}, \mathrm{P}}=15 \mathrm{~Hz}\right), 144.3$ $(\mathrm{s}), 153.2(\mathrm{~s}), 157.1\left(\mathrm{~d},{ }^{1} J_{\mathrm{C}, \mathrm{P}}=23 \mathrm{~Hz}\right), 158.3\left(\mathrm{~d},{ }^{1} J_{\mathrm{C}, \mathrm{P}}=22\right.$ $\mathrm{Hz})$; exact mass $(\mathrm{FAB}+)$ calcd for $\mathrm{C}_{49} \mathrm{H}_{51} \mathrm{O}_{2} \mathrm{P}_{2}(\mathrm{M}+\mathrm{H})$ 733.3364, found 733.3362. Anal. Calcd for $\mathrm{C}_{49} \mathrm{H}_{50} \mathrm{O}_{2} \mathrm{P}_{2}$ : C, 80.3; H, 6.88. Found: C, 80.25; H, 6.81.

2-(2,8-Dimethylphenoxaphosphino)-2'-(diphenylphosphino)-ptolyl Ether (2b). To a solution of $1.5 \mathrm{~g}$ of 2 -bromo- $2^{\prime}-(2,8-$ dimethylphenoxaphosphino)-p-tolyl ether (8) $(3.0 \mathrm{mmol})$ in 40 $\mathrm{mL}$ of THF was added dropwise $1.3 \mathrm{~mL}$ of a $2.4 \mathrm{M}$ solution of $n$-butyllithium $(3.1 \mathrm{mmol})$ at $-80{ }^{\circ} \mathrm{C}$. The resulting solution was stirred at $-80^{\circ} \mathrm{C}$ for one hour, after which $0.6 \mathrm{~mL}$ of chloro(diphenyl)phosphine $(3.1 \mathrm{mmol})$ dissolved in $10 \mathrm{~mL}$ of diethyl ether was added dropwise. The reaction mixture was stirred overnight, allowing the solution to warm slowly to room temperature. The solvents were removed in vacuo, and the resulting solid was redissolved in $40 \mathrm{~mL}$ of dichloromethane. The mixture was washed using $30 \mathrm{~mL}$ of a degassed $1 \mathrm{M}$ aqueous $\mathrm{HCl}$ solution. The organic layer was separated and dried using $\mathrm{MgSO}_{4}$. The solvents were removed in vacuo, and the resulting solid was recrystallized from dichloromethane/methanol, yielding $1.3 \mathrm{~g}$ of colorless crystals $(2.1 \mathrm{mmol}, 73 \%):{ }^{1} \mathrm{H}$ NMR $\left(\mathrm{CDCl}_{3}\right) \delta(\mathrm{ppm}) 2.05(\mathrm{~s}, 3 \mathrm{H}), 2.20(\mathrm{~s}, 3 \mathrm{H}), 2.25(\mathrm{~s}, 6 \mathrm{H}), 6.22$ $\left(\mathrm{dd},{ }^{3} J_{\mathrm{H}, \mathrm{H}}=8.0 \mathrm{~Hz},{ }^{3} J_{\mathrm{H}, \mathrm{H}}=4.5 \mathrm{~Hz}, 1 \mathrm{H}\right), 6.38\left(\mathrm{~d},{ }^{3} J_{\mathrm{H}, \mathrm{H}}=4.5\right.$ $\mathrm{Hz}, 1 \mathrm{H}), 6.43\left(\mathrm{~d},{ }^{3} J_{\mathrm{H}, \mathrm{H}}=4.2 \mathrm{~Hz}, 1 \mathrm{H}\right), 6.65\left(\mathrm{dd},{ }^{3} J_{\mathrm{H}, \mathrm{H}}=4.2 \mathrm{~Hz}\right.$, $\left.{ }^{4} J_{\mathrm{H}, \mathrm{H}}=2.2 \mathrm{~Hz}, 1 \mathrm{H}\right), 6.82\left(\mathrm{dd},{ }^{3} J_{\mathrm{H}, \mathrm{H}}=8.5 \mathrm{~Hz},{ }^{4} J_{\mathrm{H}, \mathrm{H}}=2.2 \mathrm{~Hz}\right)$, $6.94\left(\mathrm{dd},{ }^{3} J_{\mathrm{H}, \mathrm{H}}=8.5 \mathrm{~Hz},{ }^{4} J_{\mathrm{H}, \mathrm{H}}=2.2 \mathrm{~Hz}, 1 \mathrm{H}\right), 7.03\left(\mathrm{~d},{ }^{3} J_{\mathrm{H}, \mathrm{H}}=\right.$ $8.1 \mathrm{~Hz}, 2 \mathrm{H}), 7.09\left(\mathrm{dd},{ }^{3} J_{\mathrm{H}, \mathrm{H}}=8.1 \mathrm{~Hz},{ }^{4} J_{\mathrm{H}, \mathrm{H}}=1.8 \mathrm{~Hz}, 2 \mathrm{H}\right), 7.26$ $\left(\mathrm{dd},{ }^{3} J_{\mathrm{H}, \mathrm{H}}=10.5 \mathrm{~Hz},{ }^{4} J_{\mathrm{H}, \mathrm{H}}=1.8 \mathrm{~Hz}, 2 \mathrm{H}\right), 7.35-7.6(\mathrm{~m}, 10 \mathrm{H})$; ${ }^{31} \mathrm{P}\left\{{ }^{1} \mathrm{H}\right\} \operatorname{NMR}\left(\mathrm{CDCl}_{3}\right) \delta(\mathrm{ppm}),-66.3(\mathrm{~s}),-15.9(\mathrm{~s}) ;{ }^{13} \mathrm{C}\left\{{ }^{1} \mathrm{H}\right\}$ NMR $\left(\mathrm{CDCl}_{3}\right) \delta(\mathrm{ppm}), 20.7(\mathrm{~s}), 21.1(\mathrm{~s}), 117.1(\mathrm{~s}), 117.4(\mathrm{~s})$, 117.6 (s), 119.3 (s), 127.8 (s), 128.7 (s), 128.9 (s), 130.9 (s), 131.6 (s), 131.9 (s), 132.5 (s). 132.8 (s), 132.9 (s), 133.5 (s), 134.3 (s), $134.5(\mathrm{~s}), 136.0(\mathrm{~s}), 136.4(\mathrm{~s}), 137.1\left(\mathrm{~d},{ }^{1} J_{\mathrm{C}, \mathrm{P}}=11 \mathrm{~Hz}\right), 154.6(\mathrm{~s})$, $156.4\left(\mathrm{~d},{ }^{1} J_{\mathrm{C}, \mathrm{P}}=26 \mathrm{~Hz}\right), 158.3\left(\mathrm{~d},{ }^{1} J_{\mathrm{C}, \mathrm{P}}=17 \mathrm{~Hz}\right)$; exact mass (FAB+) calcd for $\mathrm{C}_{40} \mathrm{H}_{35} \mathrm{O}_{2} \mathrm{P}_{2}(\mathrm{M}+\mathrm{H})$ 609.2112, found 609.2117. Anal. Calcd for $\mathrm{C}_{40} \mathrm{H}_{34} \mathrm{O}_{2} \mathrm{P}_{2}$ : C, 78.93; H, 5.63. Found: C, 78.58; H, 5.54.

2,2'-Bis(1,1'-dimethylphenoxaphosphino)-p-tolyl Ether (2c). To a solution of $2.0 \mathrm{~g}$ of $p$-tolyl ether $(10 \mathrm{mmol})$ and $3.5 \mathrm{~mL}$ of TMEDA (23 mmol, TMEDA $=N, N, N^{\prime}, N^{\prime}$-tetramethylethylenediamine) in $50 \mathrm{~mL}$ of ether was added $9.25 \mathrm{~mL}$ of a $2.5 \mathrm{M}$ solution of $n$-butyllithium $(23 \mathrm{mmol})$ at $0{ }^{\circ} \mathrm{C}$. The solution was allowed to warm to room temperature and was stirred overnight. The resulting suspension was cooled to $-80{ }^{\circ} \mathrm{C}$, and $6.1 \mathrm{~g}$ of 2,8-dimethylphenoxyphosphine chloride (23 mmol) in $100 \mathrm{~mL}$ of toluene was added. The mixture was stirred overnight, allowing the temperature of the solution to rise to room temperature. The solvents were removed in vacuo. The resulting sticky solid was dissolved in $100 \mathrm{~mL}$ of dichloromethane. The mixture was quenched with $60 \mathrm{~mL}$ of degassed water. The water layer was extracted with $5 \times 60 \mathrm{~mL}$ of dichloromethane, and the combined organic layers were dried using $\mathrm{MgSO}_{4}$. The solvent was removed in vacuo. The product was recrystallized from dichloromethane/ethanol, yielding $4.0 \mathrm{~g}$ of colorless crystals (6.1 mmol, 61\%): ${ }^{1} \mathrm{H}$ NMR $\left(\mathrm{CDCl}_{3}\right) \delta(\mathrm{ppm}) 2.10(\mathrm{~s}, 6 \mathrm{H}), 2.20$ 
(bs, $12 \mathrm{H}), 5.94\left(\mathrm{dd},{ }^{3} J_{\mathrm{H}, \mathrm{H}}=8.1 \mathrm{~Hz},{ }^{4} J_{\mathrm{H}, \mathrm{H}}=5.3 \mathrm{~Hz}, 2 \mathrm{H}\right), 6.36$ $\left(\mathrm{d},{ }^{4} J_{\mathrm{H}, \mathrm{H}}=5.3 \mathrm{~Hz}, 2 \mathrm{H}\right), 6.72\left(\mathrm{~d},{ }^{3} J_{\mathrm{H}, \mathrm{H}}=8.1 \mathrm{~Hz}, 2 \mathrm{H}\right), 7.0-7.8$ $(\mathrm{m}, 12 \mathrm{H}) ;{ }^{31} \mathrm{P}\left\{{ }^{1} \mathrm{H}\right\} \mathrm{NMR}\left(\mathrm{CDCl}_{3}\right) \delta(\mathrm{ppm}),-62.3(\mathrm{~s}) ;{ }^{13} \mathrm{C}\left\{{ }^{1} \mathrm{H}\right\}$ NMR $\left(\mathrm{CDCl}_{3}\right) \delta(\mathrm{ppm}), 20.7$ (s), 21.1 (s), 117.6 (s), 117.9 (s), $118.5(\mathrm{~s}), 130.5(\mathrm{~s}), 130.8(\mathrm{~s}), 131.8(\mathrm{~s}), 132.7(\mathrm{~s}), 133.1\left(\mathrm{~d},{ }^{1} J_{\mathrm{P}, \mathrm{C}}=\right.$ $11 \mathrm{~Hz}), 136.4(\mathrm{~s}), 136.9(\mathrm{~s}), 155.3(\mathrm{~s}), 147.3\left(\mathrm{~d},{ }^{1} J_{\mathrm{P}, \mathrm{C}}=15 \mathrm{~Hz}\right)$; exact mass $(\mathrm{FAB}+)$ calcd for $\mathrm{C}_{42} \mathrm{H}_{37} \mathrm{O}_{3} \mathrm{P}_{2}(\mathrm{M}+\mathrm{H})$ 651.2218, found 651.2221. Anal. Calcd for $\mathrm{C}_{42} \mathrm{H}_{36} \mathrm{O}_{3} \mathrm{P}_{2}$ : C, 77.53; H, 5.58. Found: C, 77.41; H, 5.34

1-(2,8-Dimethylphenoxaphosphino)-1' -(diphenylphosphino)ferrocene $(3 \mathbf{b})$. To a solution of $2.7 \mathrm{~g}$ of 1-bromo-1'-diphenylphosphinoferrocene $(6.0 \mathrm{mmol})$ in $40 \mathrm{~mL}$ of diethyl ether was added dropwise $2.8 \mathrm{~mL}$ of a $2.4 \mathrm{M}$ solution of $n$-butyllithium $(6.7 \mathrm{mmol})$ at $-80^{\circ} \mathrm{C}$. The mixture was stirred for $1 \mathrm{~h}$. To this mixture was added dropwise a solution of $1.9 \mathrm{~g}$ of 2,8-dimethylphenoxaphosphine chloride $(7.2 \mathrm{mmol})$ in $30 \mathrm{~mL}$ of toluene. The solution was stirred overnight, allowing the temperature of the mixture to rise to room temperature. The solvents were removed in vacuo. Then $50 \mathrm{~mL}$ of dichloromethane was added, and the mixture was quenched using $20 \mathrm{~mL}$ of degassed water. The organic layer was separated, and the water layer was washed with $2 \times 10 \mathrm{~mL}$ of dichloromethane. The combined organic layers were dried over $\mathrm{MgSO}_{4}$. The solvent was removed in vacuo. The yellow solid was washed with $2 \times 20 \mathrm{~mL}$ of pentane. The compound was recrystallized from dichloromethane/methanol, yielding $1.9 \mathrm{~g}$ of orange-red crystals $(3.1 \mathrm{mmol}, 52 \%)$ : ${ }^{1} \mathrm{H}$ NMR $\left(\mathrm{C}_{6} \mathrm{D}_{6}\right)$ $\delta(\mathrm{ppm}), 2.07$ (s, 6H), 3.93 (s, 2H), 4.08 (s, 2H), 4.29 (s, 4H), 4.21 $(\mathrm{s}, 2 \mathrm{H}), 6.88\left(\mathrm{bd},{ }^{3} J_{\mathrm{H}, \mathrm{H}}=8.2 \mathrm{~Hz}, 2 \mathrm{H}\right), 7.14\left(\mathrm{~d},{ }^{3} J_{\mathrm{H}, \mathrm{H}}=8.2 \mathrm{~Hz}\right.$, 2H), 7.20 (bs, 2H), $7.52(\mathrm{~m}, 10 \mathrm{H}) ;{ }^{31} \mathrm{P}\left\{{ }^{1} \mathrm{H}\right\}$ NMR $\left(\mathrm{CDCl}_{3}\right)$ $\delta(\mathrm{ppm}),-66.7(\mathrm{~s}),-16.6(\mathrm{~s}) ;{ }^{13} \mathrm{C}\left\{{ }^{1} \mathrm{H}\right\}$ NMR $\left(\mathrm{C}_{6} \mathrm{D}_{6}\right) \delta(\mathrm{ppm})$, $20.6(\mathrm{~s}), 72.2(\mathrm{~s}), 72.7\left(\mathrm{~d},{ }^{1} J_{\mathrm{C}, \mathrm{P}}=15 \mathrm{~Hz}\right), 74.0\left(\mathrm{~d},{ }^{1} J_{\mathrm{C}, \mathrm{P}}=15 \mathrm{~Hz}\right)$, $77.5\left(\mathrm{~d},{ }^{1} J_{\mathrm{C}, \mathrm{P}}=9 \mathrm{~Hz}\right), 82.7\left(\mathrm{~d},{ }^{1} J_{\mathrm{C}, \mathrm{P}}=21 \mathrm{~Hz}\right), 117.7(\mathrm{~s}), 120.0(\mathrm{~s})$, 128.6 (s), 131.8 (s), $132.7\left(\mathrm{~d},{ }^{1} J_{\mathrm{C}, \mathrm{P}}=12 \mathrm{~Hz}\right), 133.9\left(\mathrm{~d},{ }^{1} J_{\mathrm{C}, \mathrm{P}}=\right.$ $20 \mathrm{~Hz}), 135.4(\mathrm{~s}), 135.8(\mathrm{~s}), 139.7\left(\mathrm{~d},{ }^{1} J_{\mathrm{C}, \mathrm{P}}=11 \mathrm{~Hz}\right), 154.8(\mathrm{~s})$; exact mass $\left(\mathrm{FAB}+\right.$ ) calcd for $\mathrm{C}_{36} \mathrm{H}_{31} \mathrm{FeOP}_{2}(\mathrm{M}+\mathrm{H})$ 597.1200, found 597.1200. Anal. Calcd for $\mathrm{C}_{36} \mathrm{H}_{30} \mathrm{FeOP}_{2}$ : C, 72.50; H, 5.07. Found: C, 72.42; H, 5.15.

1,2-Bis(1,1'-dimethylphenoxaphosphino)ferrocene (3c). To a solution of $3 \mathrm{~g}$ of ferrocene $(16 \mathrm{mmol})$ and $5.6 \mathrm{~mL}$ of TMEDA $(36.8 \mathrm{mmol})$ in $50 \mathrm{~mL}$ of ether was added $16 \mathrm{~mL}$ of a $2.5 \mathrm{M}$ solution of $n$-butyllithium $(40 \mathrm{mmol})$ at $0{ }^{\circ} \mathrm{C}$. The solution was allowed to come to room temperature and was stirred overnight. The resulting suspension was cooled to $-80^{\circ} \mathrm{C}$, and $9.8 \mathrm{~g}$ of 2,8 dimethylphenoxyphosphine chloride $(37.3 \mathrm{mmol})$ in $100 \mathrm{~mL}$ of toluene was added. The mixture was stirred overnight, allowing the temperature of the solution to rise to room temperature. The solvents were removed in vacuo. The resulting dark brown oil was dissolved in $50 \mathrm{~mL}$ of dichloromethane. The mixture was quenched using $60 \mathrm{~mL}$ of degassed water. The water layer was extracted with $5 \times 60 \mathrm{~mL}$ of dichloromethane, and the combined organic layers were dried using $\mathrm{MgSO}_{4}$. The solvent was removed in vacuo. The product was recrystallized from dichloromethane/ethanol, yielding $4.46 \mathrm{~g}$ of red crystals $(7.0 \mathrm{mmol}$, $44 \%):{ }^{1} \mathrm{H}$ NMR $\left(\mathrm{CDCl}_{3}\right) \delta(\mathrm{ppm}), 2.35(\mathrm{~s}, 12 \mathrm{H}), 3.83(\mathrm{bd}$, $\left.{ }^{3} J_{\mathrm{H}, \mathrm{P}}=2.0 \mathrm{~Hz}, 4 \mathrm{H}\right), 4.08(\mathrm{~s}, 4 \mathrm{H}), 7.07\left(\mathrm{~d}, 4 \mathrm{H},{ }^{3} J_{\mathrm{H}, \mathrm{H}}=8.1\right.$ $\mathrm{Hz}), 7.17\left(\mathrm{dd},{ }^{3} J_{\mathrm{H}, \mathrm{H}}=8.1 \mathrm{~Hz},{ }^{4} J_{\mathrm{H}, \mathrm{H}}=1.8 \mathrm{~Hz}, 4 \mathrm{H}\right), 7.38(\mathrm{bdd}$, $\left.{ }^{3} J_{\mathrm{H}, \mathrm{P}}=10.9 \mathrm{~Hz},{ }^{4} J_{\mathrm{H}_{\mathrm{H}}}=1.8 \mathrm{~Hz}, 4 \mathrm{H}\right) ;{ }^{31} \mathrm{P}\left\{{ }^{1} \mathrm{H}\right\} \mathrm{NMR}\left(\mathrm{CDCl}_{3}\right)$ $\delta(\mathrm{ppm}),-66.64(\mathrm{~s}) ;{ }^{13} \mathrm{C}\left\{{ }^{1} \mathrm{H}\right\} \mathrm{NMR}\left(\mathrm{CDCl}_{3}\right) \delta(\mathrm{ppm}), 20.0(\mathrm{~s})$, $71.3(\mathrm{~s}), 72.2\left(\mathrm{~d},{ }^{1} J_{\mathrm{C}, \mathrm{P}}=15 \mathrm{~Hz}\right), 82.1\left(\mathrm{~d},{ }^{1} J_{\mathrm{C}, \mathrm{P}}=19 \mathrm{~Hz}\right), 117.8$ (s), $119.4(\mathrm{~s}), 132.1(\mathrm{~s}), 133.1\left(\mathrm{~d},{ }^{1} J_{\mathrm{C}, \mathrm{P}}=12 \mathrm{~Hz}\right), 135.0(\mathrm{~d}$, $\left.1 J_{\mathrm{C}, \mathrm{P}}=38 \mathrm{~Hz}\right), 154.2(\mathrm{~s})$; exact mass $(\mathrm{FAB}+)$ calcd for $\mathrm{C}_{38} \mathrm{H}_{33} \mathrm{FeO}_{2} \mathrm{P}_{2}(\mathrm{M}+\mathrm{H})$ 639.1305, found 639.1309. Anal. Calcd for $\mathrm{C}_{38} \mathrm{H}_{32} \mathrm{FeO}_{2} \mathrm{P}_{2}$ : C, 71.49; H, 5.05. Found: C, 71.37; H, 5.11.

1-(2,8-Dimethylphenoxaphosphino)-2-(diphenylphosphino)benzene (4b). To $1.34 \mathrm{~g}$ of (2-bromophenyl)(diphenyl)phosphine $(3.9 \mathrm{mmol})$ in $40 \mathrm{~mL}$ of diethyl ether was added dropwise $1.6 \mathrm{~mL}$ of a $2.5 \mathrm{M}$ solution of $n$-butyllithium $(4.0 \mathrm{mmol})$ at $-80^{\circ} \mathrm{C}$. After $15 \mathrm{~min}, 1.1 \mathrm{~g}$ of 2,8-dimethylphenoxaphosphine chloride $(4.2 \mathrm{mmol})$ suspended in $20 \mathrm{~mL}$ of diethyl ether was added. The solution was stirred overnight, allowing the temperature of the mixture to rise to room temperature. The solvents were removed in vacuo. Then $50 \mathrm{~mL}$ of dichloromethane was added, and the mixture was quenched using $60 \mathrm{~mL}$ of degassed water. The water layer was extracted with $3 \times$ $10 \mathrm{~mL}$ of dichloromethane, and the combined organic layers were dried using $\mathrm{MgSO}_{4}$. The solvent was removed in vacuo. The product was recrystallized from dichloromethane/methanol, yielding $1.8 \mathrm{~g}$ of white crystals $(3.7 \mathrm{mmol}, 94 \%):{ }^{1} \mathrm{H}$ NMR $\left(\mathrm{CDCl}_{3}\right) \delta(\mathrm{ppm}), 2.18(\mathrm{~s}$, $6 \mathrm{H}), 6.96(\mathrm{~m}, 1 \mathrm{H}), 7.00$ (bs, 1H), 7.05 (bs, 1H), 7.09 (bd, 4H), $7.14(\mathrm{~m}, 2 \mathrm{H}), 7.28(\mathrm{~m}, 1 \mathrm{H}), 7.40(\mathrm{bd}, 4 \mathrm{H}), 7.42(\mathrm{bs}, 6 \mathrm{H}) ;{ }^{31} \mathrm{P}\left\{{ }^{1} \mathrm{H}\right\}$ NMR $\left(\mathrm{CDCl}_{3}\right) \delta(\mathrm{ppm}),-11.7\left(\mathrm{~d},{ }^{3} J_{\mathrm{P}, \mathrm{P}}=162 \mathrm{~Hz}\right),-62.9(\mathrm{~d}$, $\left.{ }^{3} J_{\mathrm{P}, \mathrm{P}}=162 \mathrm{~Hz}\right) ;{ }^{13} \mathrm{C}\left\{{ }^{1} \mathrm{H}\right\} \mathrm{NMR}\left(\mathrm{CDCl}_{3}\right) \delta(\mathrm{ppm}), 20.8(\mathrm{~s}), 117.7$ (s), 118.6(s), $128.9(\mathrm{~s}), 129.3(\mathrm{~s}), 129.8(\mathrm{~s}), 131.7(\mathrm{~s}), 133.4\left(\mathrm{~d},{ }^{1} J_{\mathrm{C}, \mathrm{P}}=\right.$ $51 \mathrm{~Hz}), 133.8\left(\mathrm{~d},{ }^{1} J_{\mathrm{C}, \mathrm{P}}=7 \mathrm{~Hz}\right), 134.4(\mathrm{~s}), 135.1(\mathrm{~s}), 135.5(\mathrm{~s}), 137.8$ (bs), 153.7 (s); exact mass (FAB+) calcd for $\mathrm{C}_{32} \mathrm{H}_{27} \mathrm{OP}_{2}(\mathrm{M}+\mathrm{H})$ 489.1537, found 489.1534. Anal. Calcd for $\mathrm{C}_{32} \mathrm{H}_{26} \mathrm{OP}_{2}$ : C, 78.68; $\mathrm{H}$, 5.36. Found: C, 78.58; H, 5.31.

Bis(2,8-dimethylphenoxaphosphino)benzene (4c). To a solution of $120 \mathrm{mg}$ of $2,2^{\prime}$-dibromo- $p$-tolyl ether $(0.34 \mathrm{mmol})$ in $10 \mathrm{~mL}$ of diethyl ether was added dropwise $1.0 \mathrm{~mL}$ of a $1.4 \mathrm{M}$ solution of tert-butyllithium $(1.4 \mathrm{mmol})$ at $-80^{\circ} \mathrm{C}$. The solution was stirred for one hour at $-80^{\circ} \mathrm{C}$ and subsequently allowed to warm slowly to room temperature. The solution was stirred at room temperature for two additional hours. The resulting yellow solution was added dropwise over a period of one hour to a solution of $100 \mathrm{mg}$ of 1-(2,8-dimethylphenoxaphosphino)2-(dichlorophosphino)benzene (7) $(0.25 \mathrm{mmol})$ in $15 \mathrm{~mL}$ of diethyl ether at room temperature. The resulting suspension was stirred overnight at room temperature. Solvents were removed in vacuo, and the resulting solid was dissolved in $20 \mathrm{~mL}$ of dichloromethane. The mixture was quenched using $20 \mathrm{~mL}$ of a degassed $1 \mathrm{M}$ aqueous $\mathrm{HCl}$ solution. The organic layer was separated, and the aqueous layer was washed using $2 \times$ $10 \mathrm{~mL}$ of dichloromethane. The combined organic layers were dried using $\mathrm{MgSO}_{4}$, and subsequently, the mixture was filtered over a plug of dry silica. Removal of the solvent yielded $0.15 \mathrm{~g}$ of a white solid. The product was recrystallized from dichloromethane/methanol, yielding $103 \mathrm{mg}$ of colorless crystals $(0.2 \mathrm{mmol}, 79 \%):{ }^{1} \mathrm{H}$ NMR $\left(\mathrm{CDCl}_{3}\right) \delta(\mathrm{ppm}), 2.23(\mathrm{~s}$, $12 \mathrm{H}), 7.01(\mathrm{bs}, 4 \mathrm{H}), 7.07\left(\mathrm{~d},{ }^{3} J_{\mathrm{H}, \mathrm{H}}=8.2 \mathrm{~Hz}, 2 \mathrm{H}\right), 7.09(\mathrm{~s}$, $4 \mathrm{H}), 7.13\left(\mathrm{bd},{ }^{3} J_{\mathrm{H}, \mathrm{H}}=8.2 \mathrm{~Hz}, 2 \mathrm{H}\right), 7.20\left(\mathrm{bt},{ }^{3} J_{\mathrm{H}, \mathrm{H}}=8.1 \mathrm{~Hz}\right.$, $4 \mathrm{H}) ;{ }^{31} \mathrm{P}\left\{{ }^{1} \mathrm{H}\right\} \mathrm{NMR}\left(\mathrm{CDCl}_{3}\right) \delta(\mathrm{ppm}),-59.5(\mathrm{~s}) ;{ }^{13} \mathrm{C}\left\{{ }^{1} \mathrm{H}\right\} \mathrm{NMR}$ $\left(\mathrm{CDCl}_{3}\right) \delta(\mathrm{ppm}), 20.8(\mathrm{~s}), 117.7(\mathrm{~s}), 119.0(\mathrm{~s}), 127.9(\mathrm{~s}), 131.5(\mathrm{~s})$, $133.0(\mathrm{~s}), 133.1\left(\mathrm{~d},{ }^{1} J_{\mathrm{C}, \mathrm{P}}=5.0 \mathrm{~Hz}\right), 134.5\left(\mathrm{~d},{ }^{1} J_{\mathrm{C}, \mathrm{P}}=38 \mathrm{~Hz}\right)$, $135.1\left(\mathrm{~d},{ }^{1} J_{\mathrm{C}, \mathrm{P}}=17 \mathrm{~Hz}\right), 145.9(\mathrm{bs}), 153.7(\mathrm{~s})$; exact mass $(\mathrm{FAB}+)$ calcd for $\mathrm{C}_{34} \mathrm{H}_{29} \mathrm{O}_{2} \mathrm{P}_{2}(\mathrm{M}+\mathrm{H})$ 531.1643, found 531.1659. Anal. Calcd for $\mathrm{C}_{34} \mathrm{H}_{28} \mathrm{O}_{2} \mathrm{P}_{2}$ : C, 76.97; H, 5.32. Found: C, 76.86; H, 5.27.

$\mathrm{X}$-ray crystal structure determination of ligand $4 \mathbf{c}$ : $\mathrm{C}_{34} \mathrm{H}_{28} \mathrm{O}_{2} \mathrm{P}_{2}$, $\mathrm{fw}=530.50$, colorless block, $0.30 \times 0.30 \times 0.30 \mathrm{~mm}^{3}$, monoclinic, $C 2 / c$ (no. 15), $a=25.2531(18) \AA, b=7.8060(4) \AA, c=17.0051(8)$ $\AA, \beta=126.849(3)^{\circ}, V=2682.4(3) \AA^{3}, Z=4, D_{\text {calc }}=1.314 \mathrm{~g} / \mathrm{cm}^{3}$, $\mu=0.193 \mathrm{~mm}^{-1} ; 34055$ reflections were measured at a temperature of $150(2) \mathrm{K}$ up to a resolution of $(\sin \theta / \lambda)_{\max }=0.65 \AA^{-1}$ on a Nonius KappaCCD diffractometer with rotating anode and graphite monochromator $(\lambda=0.71073 \AA)$. The intensities were obtained with Eval1 $4^{35}$ using an accurate description of the crystal form and the diffraction geometry. An absorption correction based on multiple measured reflections was applied ${ }^{36}(0.84-0.94$ correction range). A total of 3086 reflections were unique $\left(R_{\text {int }}=0.019\right)$. The structure was solved with Direct Methods and refined with SHELXL- $97^{37}$ on $F^{2}$ of all reflections. Non-hydrogen atoms were refined freely with anisotropic displacement parameters. All hydrogen atoms were located in the difference Fourier map and refined freely with isotropic displacement parameters. A total of

(35) Duisenberg, A. J. M.; Kroon-Batenburg, L. M. J.; Schreurs, A. M. M. J. Appl. Crystallogr. 2003, 36, 220.

(36) Sheldrick, G. M. SADABS, Area-Detector Adsorption Correction.

(37) Sheldrick, G. M. SHELXS-97, Program for Crystal Structure Refinement. 
174 parameters were refined with no restraints. R1/wR2 [I> 2o(I)]: 0.0306/0.0806. R1/wR2 [all reflns]: 0.0340/0.0830. $S=$ 1.034. Residual electron density between -0.24 and $0.37 \mathrm{e} / \AA^{3}$. Geometry calculations, drawings, and checking for higher symmetry were performed with the PLATON package. ${ }^{38}$

5.4. High-Pressure Studies. Hydroformylation of 1-Octene. The hydroformylation experiments were performed in a stainless steel (SS 316) autoclave (196 mL). The autoclave was stirred mechanically and equipped with a separate reservoir, a pressure transducer, and a thermocouple. In a typical experiment, $\mathrm{Rh}$ (acetylacetonate) $(\mathrm{CO})_{2}(5 \mathrm{mg}, 20 \mu \mathrm{mol})$ and 10 equivalents of ligand were dissolved in $15.0 \mathrm{~mL}$ of toluene under an inert atmosphere. The autoclave was placed under vacuum for $30 \mathrm{~min}$ and subsequently purged three times using 15 bar of $\mathrm{H}_{2} / \mathrm{CO}$. The catalyst solution was introduced into the autoclave via a syringe. The autoclave was purged an additional three times using $15 \mathrm{bar}$ of $\mathrm{H}_{2} / \mathrm{CO}$ and then pressurized to 15 bar and heated to $80{ }^{\circ} \mathrm{C}$. The solution was stirred at this temperature for $3 \mathrm{~h}$. A mixture of 1-octene ( $2 \mathrm{~mL}, 12.7 \mathrm{mmol})$, decane (internal standard, $1.0 \mathrm{~mL}$, $5.1 \mathrm{mmol}$ ), and $2 \mathrm{~mL}$ of toluene was introduced to the separate reservoir and purged three times with 20.0 bar of $\mathrm{H}_{2} / \mathrm{CO}$. The substrate solution was introduced into the autoclave using overpressure, and the autoclave was pressurized to a total pressure of 20.0 bar. The hydroformylation reaction was stopped after a pressure drop of approximately 0.5 bar using a solution of tributylphosphite in toluene. The autoclave was cooled rapidly using an ice-water bath and depressurized. The experiments were performed in duplicate. The conversion, regioselectivity, and amount of isomerized alkenes were determined by GC-analysis of the reaction mixture.

High-Pressure Infrared Spectroscopy. The high-pressure infrared spectroscopic experiments were performed in a stainless steel (SS 316) $50 \mathrm{~mL}$ autoclave equipped with IRTRAN windows (ZnS, transparent up to $700 \mathrm{~cm}^{-1}, 10 \mathrm{~mm}$ i.d., optical path length $=0.4 \mathrm{~mm}$ ), a mechanical stirrer, a temperature controller, a pressure transducer, and a separate $50 \mathrm{~mL}$ second

(38) Spek, A. L. J. Appl. Crystallogr. 2003, 36, 7. chamber. In a typical experiment, Rh(acetylacetonate) $(\mathrm{CO})_{2}$ (4 mg, $15 \mu \mathrm{mol})$ and 10 equivalents of ligand $(150 \mu \mathrm{mol})$ were dissolved in $15.0 \mathrm{~mL}$ of cyclohexane under an inert atmosphere. The IR autoclave was placed under vacuum and subsequently purged three times using 22 bar of a 1:1 mixture of $\mathrm{H}_{2}$ and $\mathrm{CO}$. The catalyst solution was transferred to the autoclave via syringe. The autoclave was purged an additional three times and subsequently pressurized to 17 bar. The autoclave was heated to $40{ }^{\circ} \mathrm{C}$. Spectra were collected at regular intervals until the catalytically active species was formed. Hydrogen-deuterium exchange was performed by flushing the autoclave three times using 30 bar of $\mathrm{CO}$ and subsequently pressurizing the autoclave using 20 bar of $\mathrm{D}_{2} / \mathrm{CO}, 1: 1$.

High-Pressure NMR Spectroscopy. The high-pressure NMR spectroscopic experiments were performed in a $10 \mathrm{~mm}$ sapphire high-pressure NMR tube. In a typical experiment, Rh(acetylacetonate) $(\mathrm{CO})_{2}(6 \mathrm{mg}, 24 \mu \mathrm{mol})$ and 2.2 equivalents of ligand were dissolved in $2.0 \mathrm{~mL}$ of toluene- $d_{8}$. The solution was introduced into the NMR tube under an inert atmosphere using Schlenk techniques. The tube was purged three times using 20 bar of $\mathrm{CO}$ and subsequently pressurized using 20 bar of $\mathrm{H}_{2} / \mathrm{CO}$, 1:1. ${ }^{1} \mathrm{H}$ and ${ }^{31} \mathrm{P}\left\{{ }^{1} \mathrm{H}\right\}$ NMR spectra were collected at regular intervals until changes in the spectra were no longer observed. Fluxional behavior in the final products was analyzed using variable-temperature NMR spectroscopy (temperature range -85 to $\left.+80^{\circ} \mathrm{C}\right)$.

Acknowledgment. This work was supported by The Netherlands Organization for Scientific Research (NWO/CW). E.Z. would like to acknowledge R. Bouwer for the synthesis of ligand $\mathbf{2 c}$.

Supporting Information Available: ${ }^{1} \mathrm{H},{ }^{31} \mathrm{P}\left\{{ }^{1} \mathrm{H}\right\}$, and ${ }^{13} \mathrm{C}\left\{{ }^{1} \mathrm{H}\right\}$ NMR spectra of water- and oxygen-sensitive intermediate 7 and a CIF file giving details of the single-crystal X-ray structure determination of ligand $\mathbf{4} \mathbf{c}$. This material is available free of charge via the Internet at http://pubs.acs.org. 